\title{
DNA-Destabilizing Agents as an Alternative Approach for Targeting DNA: Mechanisms of Action and Cellular Consequences
}

\author{
Gaëlle Lenglet and Marie-Hélène David-Cordonnier \\ INSERM U-837, Jean-Pierre Aubert Research Center (JPARC), Team 4 Molecular and Cellular Targeting for Cancer Treatment, \\ Institute for Research on Cancer of Lille (IRCL), Lille F-59045, France \\ Correspondence should be addressed to Marie-Hélène David-Cordonnier, marie-helene.david@inserm.fr
}

Received 15 April 2010; Revised 27 May 2010; Accepted 3 June 2010

Academic Editor: Ashis Basu

Copyright ( $) 2010$ G. Lenglet and M.-H. David-Cordonnier. This is an open access article distributed under the Creative Commons Attribution License, which permits unrestricted use, distribution, and reproduction in any medium, provided the original work is properly cited.

\begin{abstract}
DNA targeting drugs represent a large proportion of the actual anticancer drug pharmacopeia, both in terms of drug brands and prescription volumes. Small DNA-interacting molecules share the ability of certain proteins to change the DNA helix's overall organization and geometrical orientation via tilt, roll, twist, slip, and flip effects. In this ocean of DNA-interacting compounds, most stabilize both DNA strands and very few display helix-destabilizing properties. These types of DNA-destabilizing effect are observed with certain mono- or bis-intercalators and DNA alkylating agents (some of which have been or are being developed as cancer drugs). The formation of locally destabilized DNA portions could interfere with protein/DNA recognition and potentially affect several crucial cellular processes, such as DNA repair, replication, and transcription. The present paper describes the molecular basis of DNA destabilization, the cellular impact on protein recognition, and DNA repair processes and the latter's relationships with antitumour efficacy.
\end{abstract}

\section{Introduction}

The integrity of DNA is an important aspect of cell survival, since the molecule carries hereditary information and instructs essential biological processes such as transcription and replication of living cells. Alteration of this information can lead to various diseases, including cancer. The various cancer drugs that have been used in chemotherapy over the last 60 years kill cells in different ways. In addition to the targeted therapies developed over the last two decades, many routinely used anticancer agents (topoisomerase I/II inhibitors, DNA alkylating agents, and antimetabolites) target the DNA helix itself. The empirical use of alkylating compounds in cancer treatment started in the 1940s [1]. Watson and Crick's discovery of the DNA double helix in 1953 [2] led to extensive research in the field of the interactions between small molecules (whether of natural or synthetic origin) with nucleic acids. In turn, this work prompted the widespread use of some of these molecules as anticancer agents [3-7].
The interaction between small ligands and DNA involves either (i) nonspecific binding through electrostatic interactions with the negatively charged sugar-phosphate backbone, (ii) intercalation of the ligand's planar aromatic rings between two adjacent base pairs (see Figure 1), or (iii) majoror minor-groove binding. Following DNA recognition by anticancer compounds, the subsequent interaction can either be noncovalent (DNA ligands) or covalent (alkylating agents). Whereas most DNA-interacting compounds stabilize the DNA double helix, a few display the particular ability to destabilize it-leading potentially to various cellular consequences.

\section{To Be or Not to Be a Helix}

The DNA double helix is conventionally illustrated as a spiral staircase, in which the two strands (the handrails) are stabilized by hydrogen bonds between the WatsonCrick base pairs (the steps). However, these "steps" are not stable because their noncovalent interactions are reversible. 
Depending on the DNA sequence, denaturation (melting) can be local or widespread $[8,9]$ and enables various crucial cellular processes (including DNA replication, transcription, and repair) to take place [10-12].

Both sequence specificity and interaction (whether covalent or not) with a small compound or a protein can induce tilt, roll, and twist effects (a rotation of the base pairs in the $x, y$, or $z$ axis, respectively-Figure 1) and therefore change the helix's overall organization. Furthermore, slide or flip effects can also modify the geometrical orientation of the DNA helix (Figure 1). Hence, the flip effect and (to a lesser extent) the other above-defined movements modulate the double-strand stability within the helix or at its ends. Indeed, under physiological conditions, local DNA "breathing" has been evidenced at both ends of the DNA helix [14] and B-to-Z DNA structural transitions have been observed in internal DNA regions [15] in a sequence-dependent manner $[8,16-29]$. These types of locally open DNA structures are good substrates for specific proteins (such as single-strand binding proteins, SSBPs) which can also induce the opening of a "closed" DNA helix. In addition to naturally occurring DNA breathing, the helix can also be unzipped by cellular proteins and DNA binding compounds (some of which are used in the clinic).

\section{Protein-Mediated Unzipping}

In order to achieve essential cellular processes such as DNA transcription, replication and repair, some cellular proteins are able to naturally unzip the DNA helix [30]. The most well known of these (DNA helicases) are essential players in the above-mentioned processes. The destabilization is obtained through either an active, direct separation of the two DNA strands [31-33] or a passive opening mode in which the helicase binds to the locally single-stranded DNA portion generated by base pairing fluctuation (which mostly depends on the DNA sequence and induces prebent DNA structures) [34-36]. After DNA opening, the helicase partially translocates to the generated single-stranded DNA regions and subsequently moves along the base pairs to unwind the double helix at up to $500-1000 \mathrm{bp} \cdot \mathrm{s}^{-1}$. The latter process requires $\mathrm{Mg}^{2+}$ and ATP [37]. The BLM helicase (the human RecQ helicase responsible for Bloom's syndrome, which is characterized by DNA repair deficiencies) actively destabilizes the DNA duplex and performs rapid, efficient DNA strand separation [38].

Helicases are not the only proteins with intrinsic double-strand DNA opening ability; this is also a property of replication protein A (RPA), a very efficient DNA destabilizing protein involved in many DNA metabolism processes (including repair, replication, and recombination) [39-41]. RPA is a mammalian nuclear SSBP; the SSBP family members (comprising eukaryotic, bacterial and viral proteins) can efficiently destabilize DNA helix by unwinding up to one thousand base pairs. Similarly, the mouse myeloma helix-destabilizing protein, the calf thymus hnRNP-related protein UP1 and the mammalian P8 protein (related to glyceraldehyde-3-phosphate-dehydrogenase) also present both DNA single-strand binding and DNA helixdestabilizing abilities, as evidenced in thermal denaturation measurements [42-44].

High-mobility group (HMG) proteins are structurally and functionally important chromatin components which also display DNA destabilizing activities. Indeed, melting studies have revealed that both HMG1 and HMG2 destabilize DNA in the presence of 25 to $100 \mathrm{mM} \mathrm{NaCl}$ but stabilize DNA in the absence of salt $[45,46]$. An HMG-related DNA binding domain with DNA-destabilization properties has been found within c-Abl kinase protein. Moreover, this DNA destabilization was shown to increase the extent of HMG protein binding to DNA in the vicinity of the c-Abl binding site $[47,48]$.

More recently, it has been reported that the nucleocapsid protein of HIV-1 can destabilize DNA [49] via its DNA-bending activity [50]. More specifically, the DNAdestabilization function involves the protein's first zinc finger, bearing residues Ile24 and Asn27 [51]. Similarly, a DNA destabilization process was attributed to prion protein. The latter's pathological mechanism of action involves translocation to the nucleus, where the protein binds chromatin and converts to insoluble aggregates. Using FRET-coupled DNA-melting temperature studies, prion protein was found to induce significant DNA bending, unwinding, and thus local destabilization of the DNA helix [52].

Although the above-mentioned proteins induce relatively large DNA destabilization effects, small modifications (such as base flipping) could also perturb the local stability of DNA [53]. Various DNA nucleotide excision repair (NER) proteins $[54,55]$, base excision repair proteins [56-61], and DNA methyltransferases [62, 63] (such as cytosineC5-methyltransferase [64]) are known to promote base flipping. More recently, base flipping has been described in the recognition of methylated bases by the SET and RINGassociated (SRA) domain protein UHRF-1 $[65,66]$ and DNA binding by the transcription factor NF- $\kappa \mathrm{B}[67]$.

\section{DNA Ligand-Mediated Unzipping}

Small compounds that interact noncovalently with DNA can bind to the minor or major groove between the two walls of the DNA helix, via intercalation between two planar "rungs" of the base pase staircase (Figure 1) or covalently as a result of DNA alkylation. Most of the DNA unwinding compounds with well-defined binding modes belong to the intercalating or alkylating groups.

Mono- and bis-intercalators present their intercalative rings between adjacent base pairs in parallel or perpendicular ways. This results in (i) unwinding of the DNA helix by an angle $\mathrm{x}^{\circ}$, where $\mathrm{x}^{\circ}<36^{\circ}$ (since $36^{\circ}$ is the rotation angle between two adjacent base pairs in native DNA), and (ii) subsequent elongation of the DNA ( $\Delta$ Length). The value of $x^{\circ}$ depends on the nature of the interacting compound (the rotated orange arrow in Figure 1).

With DNA alkylating agents, DNA destabilization can arise from DNA bending, base flipping, or much more extensive DNA opening (Figure 1). 


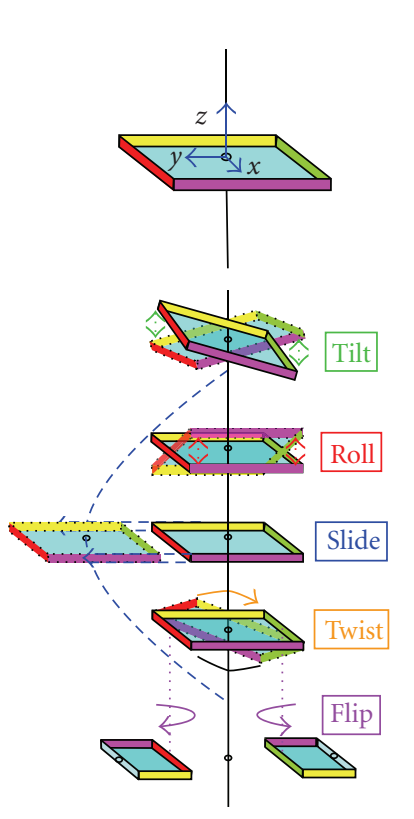

(a)

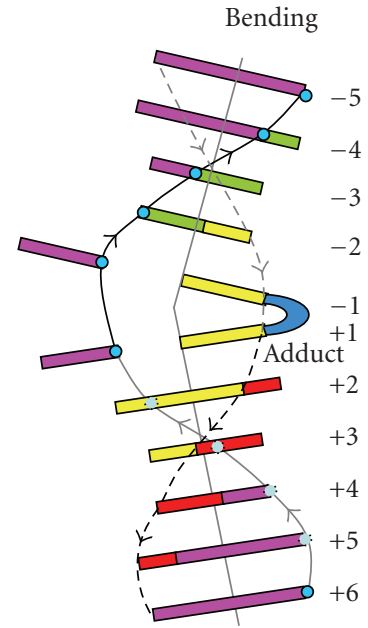

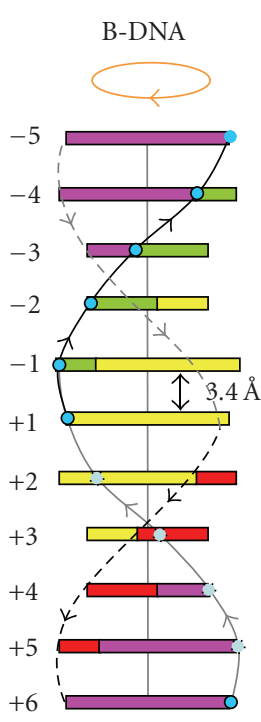

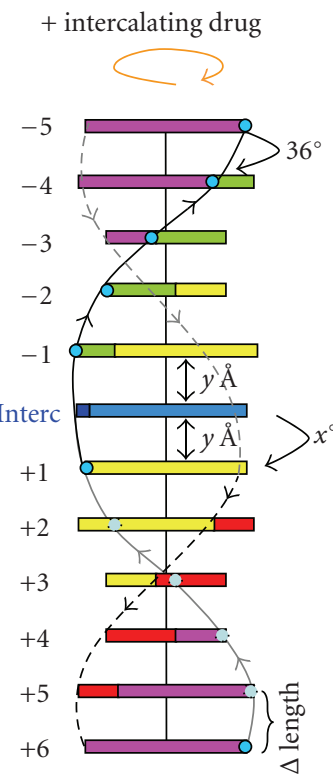

(b)

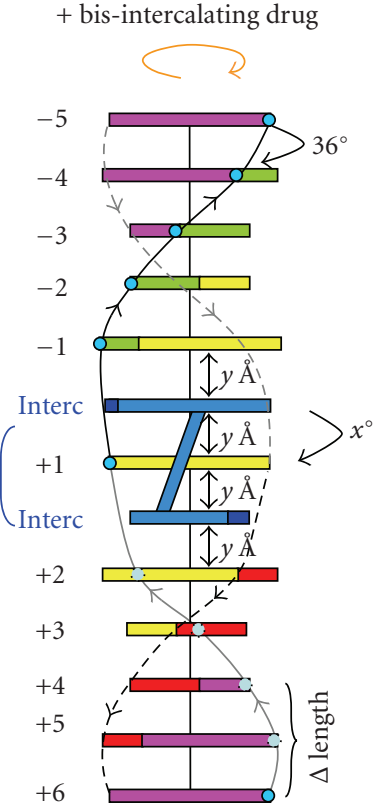

(c)

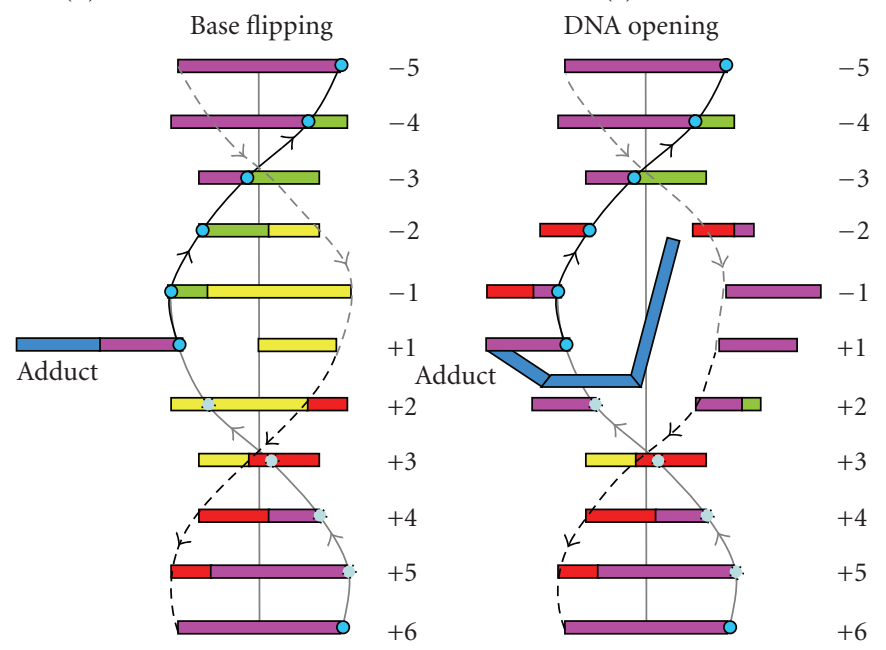

(d)

FIGURE 1: Schematic representation of DNA structure. (a) Base pair orientation with $x, y$, and $z$ axes result in different kind of rotation (tilt, roll, twist) or slipping of the bases (slide, flip) regarding to the helix central axis. (b) Native B-DNA with nearly 11 base pairs within one helix turn. (c) Mono- or bis-intercalation between adjacent base pairs result in an unwinding of the DNA helix (orange arrow on the top) and a lengthening of the DNA helix ( $\Delta$ Length) depending on the $x^{\circ}$ and $y \AA$ values that are specific for a defined DNA intercalating compound. (d) Representation of the DNA bending, base flipping, or double strand opening induced by some DNA destabilizing alkylating agents (adduct). Adapted from Calladine and Drew's schematic boxes representation [13].

4.1. DNA Intercalators. DNA-intercalating agents which impair the stability of the helix can be either mono- or bisintercalators.

4.1.1. Monointercalating Compounds. Acridine orange $(A O)$ (Figure 2) is well known for its ability to intercalate between double-stranded DNA but can also bind single-stranded DNA with high affinity. When bound to DNA, AO fluoresces at different wavelengths, depending on the nature of the nucleic acid; green fluorescence occurs after binding to double-strand DNA, whereas red luminescence results from interaction with single-strand DNA. Thermal denaturation studies suggest that the overall stability of the DNA double helix is increased by $A O$ binding [68]. However, local distortion and denaturation of double-stranded DNA are also generated, as evidenced by formaldehyde and diethylpyrocarbonate (DEPC) probing [69]. DNA denaturation after $A O$ binding was also confirmed by spectral and thermodynamic data [70] and in situ experiments [71, 72].

Ellipticine and adriamycin (Figure 2) also induce local unzipping of the DNA helix; the DNA melting temperature $\left(T_{m}\right)$ falls by 5.1 and $4.8^{\circ} \mathrm{C}$, respectively, $[69,70,75]$. As with 
<smiles>COc1cccc2c1C(=O)c1c(O)c3c(c(O)c1C2=O)CC(O)(C(=O)OCO)CC3OC1CC(N)C(C)(OC2CCCCO2)C(C)O1</smiles><smiles>Cc1c2ccncc2c(C)c2c1[nH]c1ccccc12</smiles>

Ellipticine<smiles>CN(C)c1ccc2cc3ccc(N(C)C)cc3nc2c1</smiles><smiles>[NH2+]CCNCCNCc1ccc2nc3ccc(C[NH2+]CCNCCNCc4ccc5nc6ccc(CNCC[NH2+])cc6cc5c4)cc3cc2c1</smiles>

Bis-acridine A

(a)
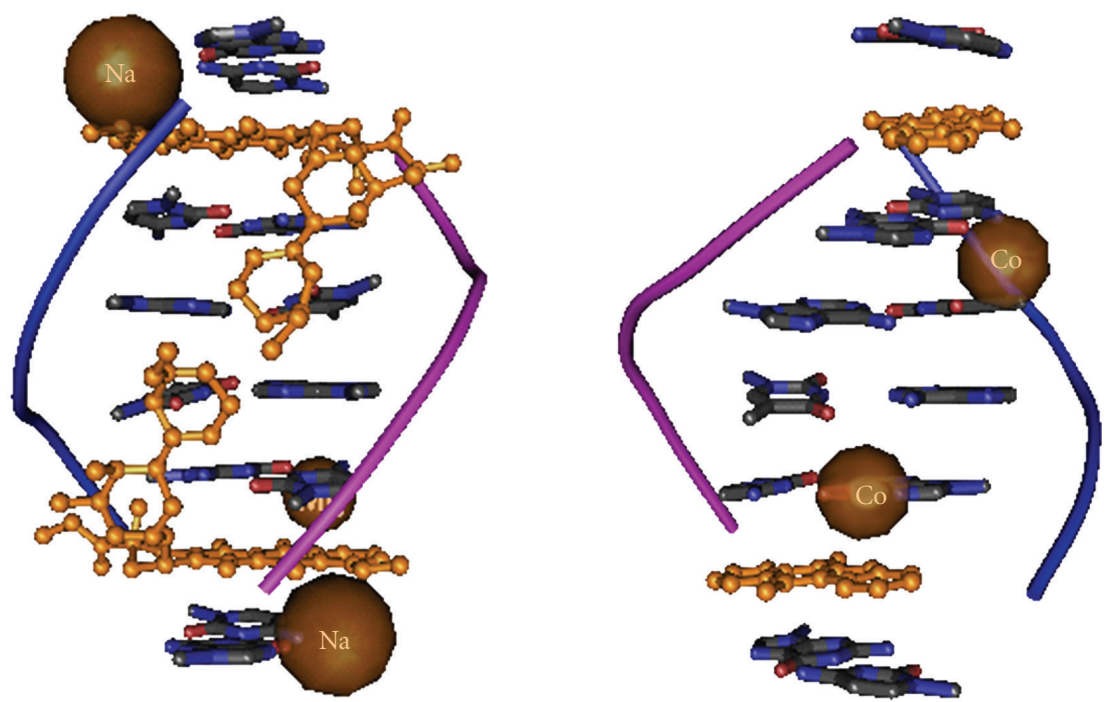

(b)

FIGURE 2: Mono- and bis-intercalating compounds inducing local destabilization of the DNA helix. (a) Structure of the compounds. (b) Three-dimensional organisation of morpholino doxorubicin bound to d(CGTACG) (left panel) and of ellipticine (right panel) intercalated between adjacent base pairs (from crystallographic data [mmdbId:52942] and [mmdbId:52189], respectively, [73, 74]).

$A O$, these two compounds bind efficiently to single-stranded DNA [76, 77]. This contrasts with ethidium bromide's binding to nucleic acids, which is highly specific for doublestranded DNA and does not destabilize the double helix [78]. Ellipticine, adriamycin, and $A O$ all intercalate between two adjacent base pairs and then subsequently change their orientation to interact with the single-stranded nucleic acid sections formed locally during DNA breathing. The singlestranded portions within the DNA helix lengthen because of cooperative binding by the intercalator, which thus leads to a higher level of DNA denaturation. This progressive unzipping of the DNA helix has also been observed in situ using cytometry, with a direct relationship between the decrease in green fluorescence and increased concentrations of $A O$ in treated cells or nuclei [72]. Furthermore, post denaturation aggregate formation was observed using electron microscopy, with DNA condensation occurring primarily in heterochromatin, ribosomal, and polysomal structures $[71,72]$.

4.1.2. Bis-Intercalating Agents. Within the bis-intercalating group of compounds, the cyclo-bis-intercalator bisacridine A (BisA) (Figure 2) also displayed DNA unwinding properties. This macrocyclic compound is composed of two acridine cores (the DNA-intercalating motifs) linked by polyammonium bridges [79]. By using a variety of complementary 
biochemical and biophysical techniques (such as fluorescence, melting temperature studies, and gel electrophoresis), Slama-Schwok et al. nicely demonstrated the ability of the polyaminomacrocycle BisA to shift the equilibrium from duplex DNA towards hairpin nucleic acid structures [80] and to destabilize double-stranded DNA [81] (two properties not observed with monoacridine derivatives). Another characteristic of BisA is its potent ability to bind singlestranded DNA. Additionally, when irradiated with light, BisA efficiently induces photocleavage through its acridine photoactive core. This activity is greater with single-stranded nucleic acids than with double-stranded nucleic acids [82]. Interestingly, NMR and molecular modelling studies of BisA compounds bound to an abasic site-containing DNA show that one acridine ring intercalates between the $\mathrm{C} \cdot \mathrm{A}$ and $\mathrm{T} \cdot \mathrm{G}$ base pairs, the second ring lies in the free space of an $\mathrm{A} \cdot \mathrm{T}$ base pairing and the linker chains are positioned in the major and minor grooves on each side [83]. On the base-pair level, T.G mismatches and $\mathrm{AP} \cdot \mathrm{T}$ recognition result in base flipping of the thymine- - suggesting that BisA sterically prevents DNA glycosylases from binding to their specific, base-damaged recognition sites [84].

4.2. DNA Alkylating Agents. Intercalating agents are reversible DNA ligands. However, some covalent DNAbinding anticancer drugs can also locally destabilize the DNA helix; these include the well-known alkylating agent cisplatin and its derivatives and the recent drug candidate S23906-1 (a benzo-acronycine derivative). This contrasts with the DNA stabilization properties of most DNAalkylating agents (whether used in chemotherapy or not), such as mitomycin $C$, some psoralen and dinuclear platinum derivatives, ecteinascidine 743 and nitrogen mustards [85-91].

4.2.1. Platinated DNA Destabilizing Agents. Cisplatin (cisdiaminedichloridoplatinum(II); Figure 3) was one of the first chemotherapeutic agents to be developed and is still frequently used in the clinic. It is able to form inter- and intrastrand crosslinks and monovalent adducts, primarily though covalent bonding to the N7 atom of guanine residues. The most common lesion is the intra-strand crosslink (occurring preferentially (65\%) at the GpG dinucleotide), followed by ApG intrastrand crosslinks (25\%). Interstrand crosslinks occur less frequently and depending on the nature of the platinated agent, with 5 to $8 \%$ for cisplatin, $12 \%$ for transplatin (Figure 3 ) and up to $30 \%$ for trans- $\mathrm{PtCl}_{2}\left(\mathrm{NH}_{3}\right)$ (quinoline) (Figure 3 ) and trans$\mathrm{PtCl}_{2}\left(\mathrm{NH}_{3}\right)$ (thiazole) derivatives. In comparison, nitrogen mustards induce 1 to $5 \%$ of inter-strand crosslinks, whereas nitrosourea and mitomycin $C$ induce 2 to $8 \%$ and 5 to $13 \%$, respectively [93-95]. Cisplatin-induced intra-strand crosslinks at GpG base pairs result in (i) bending of the DNA axis toward the major groove with an angle of 55$78^{\circ}$, and (ii) DNA distortion, enabling local denaturation of the double helix via destabilization of the Watson-Crick base pairing [96-102]. In comparison, the bending angle for inter-strand crosslinks is $45^{\circ}$ and is associated with DNA unwinding of $79 \pm 4^{\circ}$. The distortion in platinatedGpG intra-strand crosslinks is different and depends on<smiles>N[P](N)(Cl)Cl</smiles>

Cisplatin<smiles>N[PH](N)(Cl)Cl</smiles>

Transplatin<smiles>O=C1O[PH]2(N[C@H]3CCCC[C@H]3N2)OC1=O</smiles>

Oxaliplatin<smiles>N[Pb](N)(N)Cl</smiles>

$\left[\mathrm{PtCl}\left(\mathrm{NH}_{3}\right)_{3}\right]^{+}$<smiles></smiles>

$[\mathrm{PtCl}(\text { dien })]^{+}$

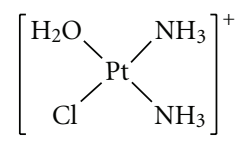

cis- $\left[\mathrm{PtCl}\left(\mathrm{NH}_{3}\right)_{2}\left(\mathrm{OH}_{2}\right)\right]^{+}$

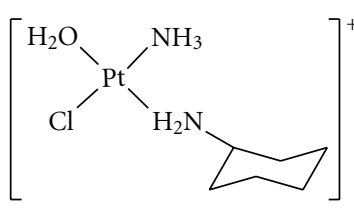

cis- $\left[\mathrm{PtCl}\left(\mathrm{NH}_{3}\right)\right.$ $\left.\left(\mathrm{c}-\mathrm{C}_{6} \mathrm{H}_{11} \mathrm{NH}_{2}\right)\left(\mathrm{OH}_{2}\right)\right]^{+}$<smiles></smiles>

trans- $\left[\mathrm{PtCl}\left(\mathrm{NH}_{3}\right)\right.$ (quinoline) $\left.\left(\mathrm{OH}_{2}\right)\right]^{+}$ (a)

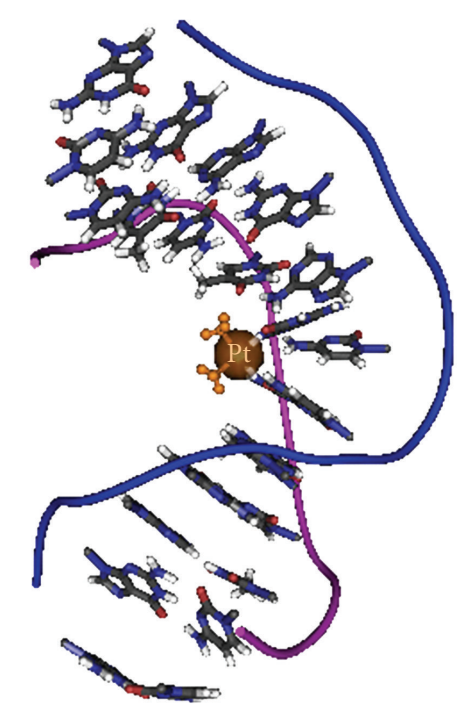

(b)

FIgURe 3: Platinium derivatives. (a) Examples of platinated agents inducing local destabilization of the DNA helix. (b) The threedimensional organization of cisplatin bound to DNA are drawn from crystallographic data [mmdbId:47796] [92] and evidenced strong DNA bending induced by cisplatin on a duplex DNA decamer oligonucleotide that fits with the L-shape angle of HMGbox DNA-binding domain.

the sequence context, with up to $7 \mathrm{bp}$ for 1,3 -intrastrand crosslinks in a TGTGT context [101]. This destabilization was found to be enthalpic (rather than entropic) in origin $[101,103]$. Similarly, cisplatin adducts occurring at the $5^{\prime}-$ TGGT sequence induce a decrease of more than $10^{\circ} \mathrm{C}$ in the melting temperature-much higher than the decrease of $6^{\circ} \mathrm{C}$ or so measured for $5^{\prime}$-CGGT and $5^{\prime}$-AGGC sequences $[104,105]$. DNA stabilization/destabilization also depends on the $\mathrm{pH}$ of the milieu [106]. In contrast to cisplatin, 
the interstrand crosslinks formed by transplatin do not destabilize the DNA helix or correlate with changes in the transition entropy or enthalpy [101, 107].

Interestingly, the third-generation platinum antitumor derivative oxaliplatin [(1R,2R-diamminocyclohexane)oxalatoplatinum-(II)] (Figure 3) was found to induce greater DNA unwinding, bending and helix destabilization than cisplatin. This correlates with the lower degree of cellular DNA damage seen after oxaliplatin treatment than after cisplatin treatment and the lower HMG protein affinity for oxaliplatin-versus cisplatin-induced damage [101]; these findings suggest that the two molecules induce different DNA repair processes/efficiencies, depending on the extent of local helix destabilization.

It is noteworthy that some other bifunctional platinated derivatives do not destabilize the DNA duplex. This is the case for pyrazolato-bridged dinuclear platinum(II) complex $\left[\left(\text { cis- }\left\{\mathrm{Pt}\left(\mathrm{NH}_{3}\right)_{2}\right\}\right)_{2}(\mathrm{mu}-\mathrm{OH})(\text { mu-pyrazolate })\right]^{2+}$, which crosslinks two adjacent guanines and unwinds the DNA by around $15^{\circ}$ but does not change the directionality of the helix axis. This absence of bending may explain the lack of DNA destabilization [108].

The DNA sequence is also important; monofunctional platinum adducts exhibit different DNA destabilizing effects depending on the base sequences surrounding the guanine target site [97, 109]. Indeed, when oligonucleotide containing platinum adducts were incubated in the presence of 50 or $500 \mathrm{mM} \mathrm{NaCl}$, the highest DNA destabilization was observed when the guanine target was located within the TGC triplet sequence (with a $\Delta T_{m}$ value of $-10.6^{\circ} \mathrm{C}$ and $-13.2^{\circ} \mathrm{C}$, resp.). For all triplets, the decrease in $T_{m}$ was greater in $500 \mathrm{mM} \mathrm{NaCl}$ buffer than in $50 \mathrm{mM} \mathrm{Na}^{+}$ counterion containing buffer. In general, the highest DNA destabilization effect was seen when the monoadduct was positioned between pyrimidine residues. Osmium tetroxide $\left(\mathrm{OsO}_{4}\right)$ and DEPC probing revealed that both thymine and the opposite adenine are crucial for the local distortion of the DNA structure by the platinum mono-adduct positioned within a $5^{\prime}$-TGC triplet but not within a $5^{\prime}$-AGT or $5^{\prime}$-TGA triplet. In contrast, none of these chemical probes reacted with the bifunctional adduct at the $5^{\prime}$-TGGT sequence [110].

Hägerlöf et al. found that the cisplatin derivatives cis- $\left.\mathrm{PtCl}\left(\mathrm{NH}_{3}\right)_{2}\left(\mathrm{OH}_{2}\right)\right]^{+}$, cis- $\left[\mathrm{PtCl}\left(\mathrm{NH}_{3}\right)\left(c-\mathrm{C}_{6} \mathrm{H}_{11} \mathrm{NH}_{2}\right)\left(\mathrm{OH}_{2}\right]^{+}\right.$, and trans- $\left[\mathrm{PtCl}\left(\mathrm{NH}_{3}\right) \text { (quinoline) }\left(\mathrm{OH}_{2}\right)\right]^{+}$destabilized both double-stranded DNA and double-stranded RNA (Figure 3). Indeed, after platination with these compounds, the melting temperatures for both the RNA and DNA hairpins fell. With hairpin RNA, platination induced much weaker destabilization, with a $\Delta T_{m}$ of $-5^{\circ} \mathrm{C}$. In the case of DNA, the platinuminduced destabilization was more pronounced, with $\Delta T_{m}$ values of around $-11^{\circ} \mathrm{C}[111]$.

4.2.2. Ruthenium-Containing Alkylators. Transition-metal antitumor agents other than platinum compounds also present DNA unwinding activity. This is the case for ruthenium derivatives such as $\left[\left(\eta^{6}-p \text {-cymene }\right) \mathrm{Ru}(\mathrm{II})(\mathrm{en})-(\mathrm{Cl})\right]^{+}$ (Ru-CYM, Figure 4). This organometallic ruthenium(II) arene complex was rationally designed on the basis that changing the metal ion from platinum to ruthenium should provide additional coordination sites in the octahedral complexes, modify the oxidation rate, and change the ligand affinity and binding kinetics for use in chemotherapy [ 7 , 112-114]. In particular, Brabec and co-workers performed $T_{m}$ studies while varying the drug/DNA ratio in buffer containing $\mathrm{NaClO}_{4}$ concentrations ranging from $0.01 \mathrm{M}$ to $0.2 \mathrm{M}[115,116] . \Delta T_{m}$ measurements at a drug/DNA ratio of 0.1 showed a decrease of up to $4^{\circ} \mathrm{C}$ in the CT-DNA melting temperature at all $\mathrm{Na}^{+}$concentrations.

This DNA helix destabilization was also observed using biphenyl $(R u-B I P)$, dihydroanthracene (Ru-DHA), and tetrahydroanthracene (Ru-THA) (Figure 4) as arenes but only at the highest concentration of $\mathrm{NaClO}_{4}$ [115]; at lower $\mathrm{Na}^{+}$-counterion concentrations, $R u-B I P, R u-D H A$ and $R u-$ THA induced DNA helix stabilization, due to a positive charge effect on the ruthenium moiety and the intercalation process. When compared with the other ruthenium arene complexes, the DNA helix destabilization activity of $R u$ $C Y M$ correlates with a smaller unwinding angle of $7^{\circ}$ (versus $14^{\circ}$ of unwinding in supercoiled plasmid DNA by $R u$ $B I P, R u-D H A$ and $R u$-THA). The Ru-CYM-induced DNAunwinding appears to be consistent with the absence of intercalation of $R u$-CYM between two adjacent base pairs and the formation of monoadducts on the N7 atom of guanine residues [116]. Ru-THA and Ru-CYM have been used as models for the repair of DNA-ruthenium complexes the compounds destabilize the DNA helix via different enthalpic effects and differ in terms of their DNA basepair intercalation propensity. DNA destabilization was also recently evidenced for new ruthenium derivatives, such as monodentate- $R$ u(II) [117].

4.2.3. Psoralen Derivatives. In terms of DNA stabilization/destabilization properties, the psoralen derivative $4^{\prime}$ (hydroxymethyl)-4, 5',8-trimethylpsoralen (HMT) (Figure 5) exerts two effects: (i) monoaddition of a psoralen residue stabilizes the double helix formed by two non-selfcomplementary oligonucleotides by as much as $1.3 \mathrm{kcal} / \mathrm{mol}$ (for a furan-side mono-adduct) or $0.7 \mathrm{kcal} / \mathrm{mol}$ (for a pyrone-side mono-adduct) at $25^{\circ} \mathrm{C}$ in $50 \mathrm{mM} \mathrm{NaCl}$; (ii) mono-addition of a psoralen residue to each of the two thymidines in the double helix in the sequence GGGTACCC destabilizes the helix by $1.8 \mathrm{kcal} / \mathrm{mol}$ at $25^{\circ} \mathrm{C}$ in $1 \mathrm{M} \mathrm{NaCl}-$ the two HMT molecules at the centre of each strand cause an unfavourable enthalpy change and a favourable entropy change [85].

4.2.4. Benzopyrene Carcinogens. In the cell, the environmental and tobacco smoke carcinogen benzo[a]pyrene $(\mathrm{BaP})$ is metabolized into (+/-)-anti-benzo [a]pyrene7,8-dihydrodiol-9,10-epoxide (BPDE) (Figure 5). The (+)$7 R, 8 S, 9 S, 10 R$ enantiomer (+)-anti-BPDE is thought to be the metabolite that is ultimately responsible for mutations, DNA damage, and cancer. By covalently linking to the exocyclic $\mathrm{NH}_{2}$ group of guanine, BPDE forms a bulky DNA adduct in the minor groove of the helix and destabilizes base pairing $[120,121]$. 


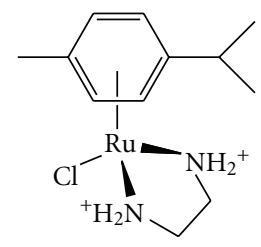

Ru-CYM

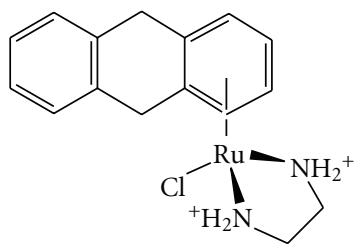

Ru-DHA

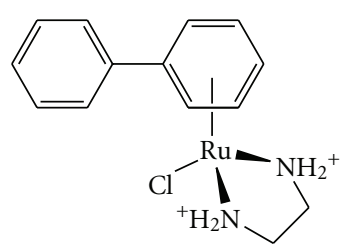

Ru-BIP<smiles></smiles>

Ru-THA
Figure 4: Ruthenium derivatives. $R u$-CYM, $R u$ - $B I P, R u-D H A$, and $\mathrm{Ru}$-THA are examples of ruthenium-containing agents inducing local destabilization of the DNA helix.

Several enantiomers are produced by the alkylation reaction which follows the opening of the epoxide group. The (+)-anti-BPDE adducts consist mostly of the carcinogenic $10 S(+)$-trans-anti-BPDE (derived from the $(+)-$ $7 R, 8 S, 9 S, 10 R$ compound) and, to a lesser extent, stereoisomeric $10 R(+)-c i s-B[a] P-N 2-d G$ adducts. The (-)-BPDE enantiomer forms (-)-trans- $B[a] P-N 2-d G$ adducts but with lower efficiency. The DNA bonding of the stereoisomeric damage suggests base displaced intercalation or minor groove conformations. Covalent adduct formation prevents the amino group of guanine from hydrogen bonding with the opposite cytosine (which otherwise stabilizes GC base pairs in the native DNA helix). This results in base flipping, with the (+)-anti-B $[a] P-N 2-d G$ bulky adduct on the guanine situated in the minor groove and the opposite cytosine aligned with the major groove $[122,123]$.

Depending on the target sequence, the bulky $10 S(+)$ trans-anti-B $[a] P-N 2-d G$ rings point in the $5^{\prime}$ direction relative to the alkylated guanine position in each case, although the exact positions are different. Indeed, using $5^{\prime}$ $\mathrm{CGG}^{*} \mathrm{C}$ DNA, the $10 S(+)$-trans-anti-B $[a] P-N 2-d G$ lesion untwists the DNA significantly and causes a large bend in the DNA helix. In contrast, with a $5^{\prime}-\mathrm{CG} * \mathrm{GC}$ sequence, no untwisting is seen but the DNA helix is destabilized $5^{\prime}$ to the lesion [124]. These structural differences result in differing electrophoretic mobility in polyacrylamide gels and different protein/DNA recognition and DNA repair efficiencies [125].

Although the $\mathrm{BaPs}$ are environmental mutagens and not antitumor agents, their very particular mode of DNA binding with dual interference on DNA repair processes could highlight useful phenomena involved in the mechanism of action of cancer drugs (such as effects on DNA repair, as described in Section 5).<smiles>Cc1oc2c(C)c3oc(=O)cc(C)c3cc2c1CO</smiles>

4'-(hydroxymethyl)4,5',8-trimethylpsoralen (HMT)<smiles>OC1C2=C(OC2)c2ccc3cccc4ccc5cc1c2-c5c34</smiles>

$(+)$-antibenzo[a]pyrene $\mathrm{O}$ (BP) diol epoxide<smiles>CC12CCC3C4=C(C=CC3C1=O)C1CCC(=O)C(=O)C=CC412</smiles>

Catechol 4-hydroxyequilenin<smiles></smiles><smiles>COc1cc2c(c3c1c(=O)c1cc4ccccc4cc1n3C)C(OC(=O)N(C)[14CH3])C(OC(=O)N(C)C)C(C)(C)O2</smiles><smiles>COc1cc2c(c3c(-c4ccccn4)c(=O)c4cc5ccccc5cc4n13)C(O)C(OC(C)=O)C(C)(C)O2</smiles><smiles>COc1cc2c(c3c1c(=O)c1cc4ccccc4cc1n3C)C(OC(C)=O)C(OC(=O)CCCC(=O)O)C(C)(C)O2</smiles>

(a)
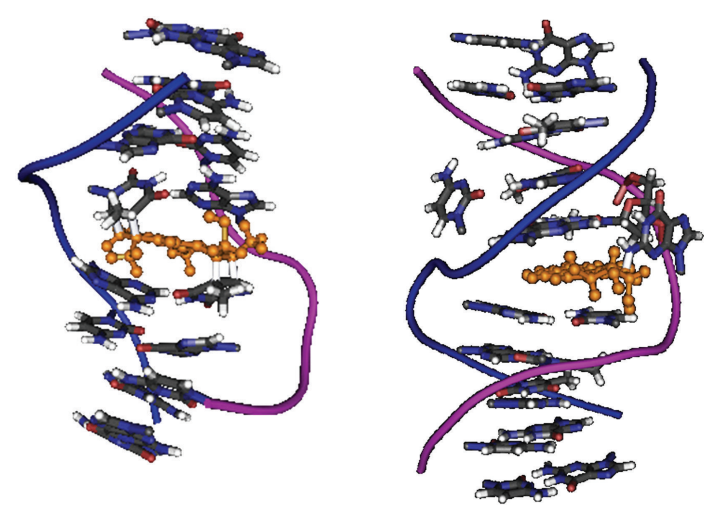

(b)

FIgURE 5: Other DNA alkylating agents inducing local destabilization of the DNA helix. (a) Structures of some DNA alkylating molecules that destabilize the DNA helix. (b) Three-dimensional organization of the psoralen derivative HMT (a) and (+)-antiBPDE (b) bound to DNA (crystallographic data [mmdbId:52343] [118] and [mmdbId:52106], respectively, [119]). 
4.2.5. 4-Hydroxyequilenin (4-OHEN). As is the case for $\mathrm{BaP}$, 4-OHEN alkylating agents are genotoxic but are not anticancer drugs. 4-OHEN compounds are derived from equine oestrogens (equilin, 3-hydroxy-1,3,5(10),7estratetren-17-one, and equilenin, 3-hydroxy-1,3,5(10),6,8estrapenten-17-one) which are present at various concentrations in the hormone substitution therapies used to reduce the side effects of the menopause but which are also thought to contribute to a greater risk of breast cancer in the treated population [126-128]. In the body, both equilin and equilenin are rapidly converted into the intermediate catechol 4-hydroxyequilenin, which is further oxidized into the reactive 4-hydroxyequilenin-o-quinone (Figure 5) [129]. This ortho-quinone form of $4-O H E N$ is a potent cytotoxic and genotoxic agent [130] and forms a bulky lesion on dA, $\mathrm{dC}$, and $\mathrm{dG}$ but not $\mathrm{T}$ residues [131-134]. This damage can be detected not only in cell culture but also in breast cancer biopsies from patients having undergone hormone substitution therapy [135]. Each of the base adducts are present as four stereoisomers, each of which induces different levels of structural distortion in duplex DNA [136-138].

4-OHEN-C adducts present an unusual cyclic core with the bulky rings pointing along the major or the minor groove depending on whether the glycosidic bond adopts a syn- or anticonformation, respectively [139]. Alkylation of an 11-bp oligonucleotide at specific $\mathrm{dA}$ or $\mathrm{dC}$ residues results in a strong decrease in the melting temperature of the double-stranded DNA, compared with the unmodified oligonucleotide. The magnitude of the decrease depends on the position of the adduct within the oligonucleotide: a 6 $9^{\circ} \mathrm{C}$ decrease in $T_{m}$ is obtained when the adduct is located 1 or 2-bp from the end of the 11-bp DNA, whereas a large (21$27^{\circ} \mathrm{C}$ ) decrease is induced when the adduct is present more centrally (positions 4 to 8 ).

The extent of the destabilization also depends on the adduct's stereoisomeric orientation, as defined using circular dichroism measurements [134], thermodynamic analyses and molecular modelling. Indeed, distortions, base-stacking characteristics, and groove sizes were found to vary according to the nature and the stereoisomerism of the bulky DNA lesion [139].

4.2.6. Benzoacronycine Derivatives. The compound S23906-1 [(+)-cis-1,2-diacetoxy-6-methoxy-3,3,14-trimethyl-1,2,314 - tetrahydro-7 $H$-benzo[ $b]$ pyrano [3,2- $h]$ acridin-7-one] (Figure 5) is a potent DNA-alkylating agent with strong cytotoxic and antitumour properties. On the basis of very promising preclinical trials, it entered clinical trials in 2006 (Servier, France). S23906-1 alkylates DNA on guanine's exocyclic amino group (located in the minor groove of the DNA helix) and thus contrasts with commonly used chemotherapeutic alkylating agents which react at guanine's N7 position in the major groove (cisplatin, nitrosourea, nitrogen mustards, etc.). This nucleophilic point is also targeted by other clinically used antitumour agents, such as ecteinascidine-743 (ET-743/trabectedin/Yondelis) developed by the company PharmaMar (Spain) [140], mitomycin-C (a dual alkylating agent which bonds to either the N2 group of guanine in the minor groove or the N7 group of guanine in the major groove) [141] and anthramycin [142].

In contrast to ET-743, mitomycin-C and the anthramycins, the alkylation of double-stranded DNA by S23906-1 results in local destabilization of the DNA helix and thus the formation of a single-stranded DNA portion that can be attacked by single-strand-specific nucleases (such as nuclease S1) [91]. This destabilization was seen with various multiple derivatives of S23906-1 (e.g., esters of the benzo [b] acronycine core, Figure 5). The dicarbamate derivative S29385-1 had a very strong effect. The DNA destabilization potency of this series was confirmed in a variety of physical and biochemical approaches. For example, quantification of the ratio between the fluorescence of Picogreen (a dye which interacts with both double- and single-stranded DNA) and ethidium bromide (BET) (a double-stranded-specific dye) revealed additional Picogreen binding and suggested that S29385-1 generates single-strand DNA (Figure 6(a)). Accordingly, DNA melting temperature studies evidenced a negative $\Delta T_{m}$ value, reflecting DNA destabilization (Figure 6(b)).

S23906-1's ability to destabilize DNA was also clearly demonstrated in biochemical approaches, such as electrophoretic mobility shift assays (generating single-stranded DNA form following alkylation of a fully double-stranded DNA fragment) and the use of nuclease-S1 single-strandspecific digestion to map the relative positions of locally DNA openings induced by alkylation (Figure 7 and [91]).

\section{Drug-Induced DNA Destabilization: Cellular Consequences}

Compounds which change the equilibrium between the stable, double-stranded DNA helix and locally destabilized strands could strongly alter protein/DNA recognition and thus have major cellular consequences. Indeed, base kinking, unstacking, and nucleotide extrusion (flipping) induce discontinuities in the double helix and thus facilitate DNA lesion/mismatch recognition [143-145]. The few literature studies to have addressed this point reveal that proteins which recognize damaged DNA are affected by the stabilization or destabilization of the DNA helix; this leads to a major impact on biological parameters such as antitumour activity, transcription factor binding potency, and DNA repair process efficiency [146-148].

This type of cellular impact has been particularly well demonstrated for the platinated adducts recognized by HMG proteins [149]. HMG/platinated DNA recognition is triggered by the strong DNA bending generated by the platinated agent (Figure 2). The large induced bend fits perfectly with the L-shaped structure of HMG DNA binding domain (HMG-box) and reduces the "cost" of DNA bending for the protein [150]. As a consequence, HMG proteins bind less well to oxaliplatin adducts than to cisplatin adducts because the former agent induces relatively greater DNA bending and thus stronger DNA destabilization [151]. This finding correlates with the lower level of DNA lesions found in cells treated with oxaliplatin, relative to cisplatin. It is assumed that HMG binding shields the platinated adducts from repair 


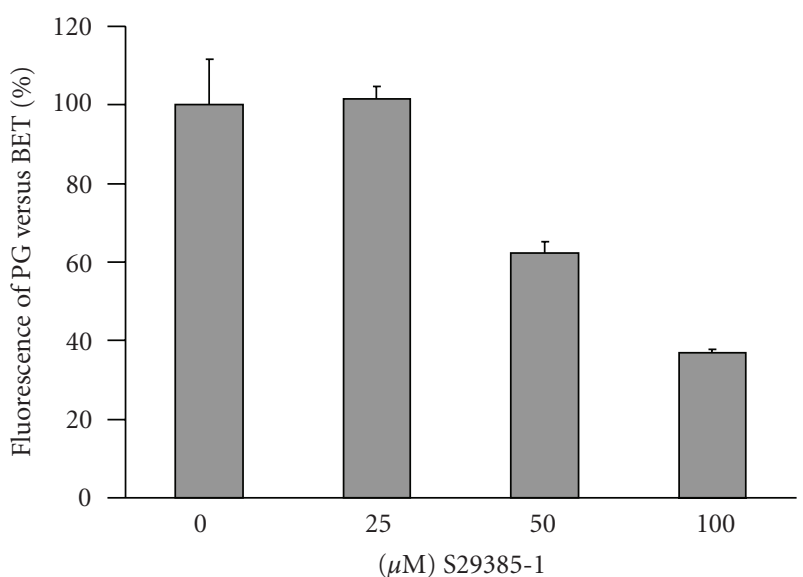

(a)

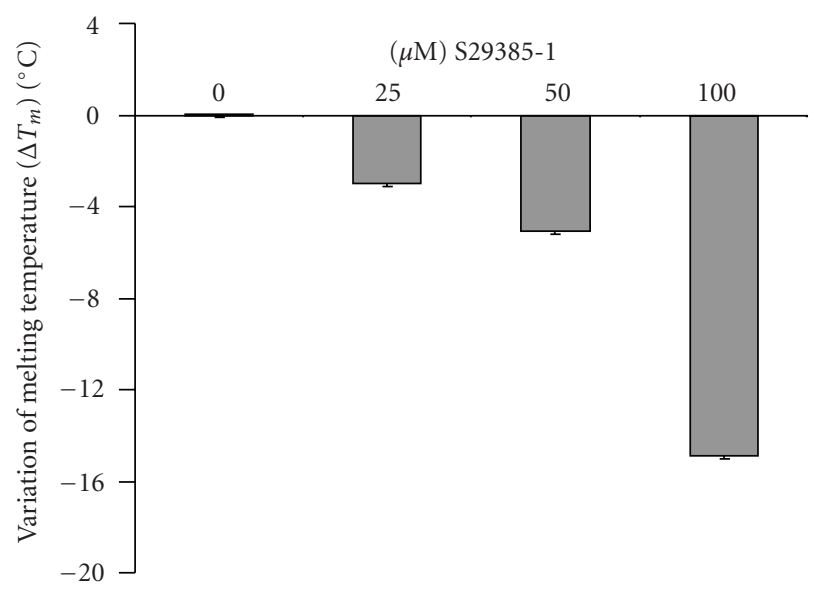

(b)

Figure 6: DNA destabilization propensities of the benzoacronycine dicarbamate derivative S29385-1. (a) CT-DNA was incubated with increasing concentrations of S29385-1 prior to the incubation with a mixture of ethidium bromide (BET) and Picogreen ( $P G$ from Molecular Probes, Invitrogen) to quantify only double-strand DNA or both double-strand and single-stranded DNA, respectively. Results are expressed as the percentage of the peak of emission for BET versus $P G$. (b) Variation of the melting temperature studies of a short 24-bp double-strand oligonucleotide incubated for 24 hours alone or with increasing concentrations of S29385-1 prior to ethanol precipitation of the sample and melting temperature measurement. The results are expressed as the melting temperature for the [DNA+drug] complex minus melting temperature for DNA alone. (Details for the corresponding experimental protocols are described in [91].)

by the human DNA excision machinery [152] and therefore participates in platinated-agent-induced cytotoxicity [153]. However, too strong a bend and greater DNA destabilization lead to a structure that does not fit perfectly with L-shaped HMG-box, thus resulting in a weaker HMG protein binding. The weaker HMG binding to oxaliplatin adducts corresponds to weaker protection from DNA repair and so oxaliplatinDNA lesions are more efficiently repaired than cisplatininduced lesions. This results in a lower number of lesions in cells for oxaliplatin than for cisplatin. Moreover, bent

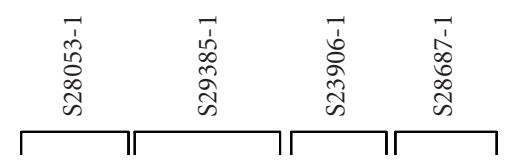

$\begin{array}{llllllllllllll}0 & 10 & 20 & 0 & 1 & 2 & 5 & 0 & 10 & 20 & 0 & 10 & 20 & 0\end{array}$

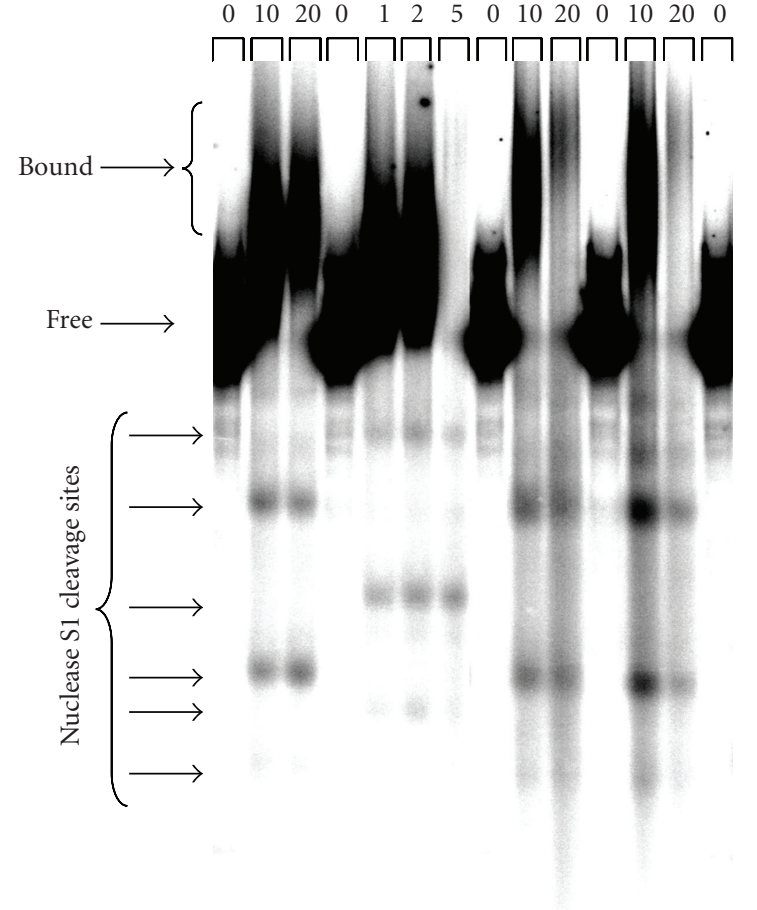

FIGURE 7: Nuclease S1 mapping of locally opened DNA structure. Increasing concentrations of the benzo-b-acronycine derivatives presented in Figure 5 were incubated with a radio-labelled 117bp DNA fragment prior to subjection to nuclease S1 mapping of the induced locally single-stranded DNA portions generated upon DNA alkylation. DNA samples were separated on a $10 \%$ native polyacrylamide gel. Concentrations are expressed in $\mu \mathrm{M}$. The detailed experimental protocol is described in [91].

platinated-DNA is a good substrate for transcription factors such as SRY and LEF-1 (which belong to the HMG-box family, regarding their DNA-binding domain) and explains the observation of transcriptional changes in treated cells $[92,154-156]$.

Regarding DNA repair, the local destabilization of the double helix, base flipping and poor base stacking all play a role in the recognition of DNA lesions by repair proteins [157-160]. This has been well demonstrated for the MSH2/MSH6 heterodimer mismatch repair complex (Mut-S alpha), which recognizes not only mismatched bases but also certain DNA lesions, such as cisplatin (but not transplatin) crosslinks [161-165].

In the case of ruthenium-derivative-induced DNA lesions, the NER machinery appears to be less efficient than for platinum adducts. Interestingly, $R u-C Y M$ adducts (which destabilize the DNA helix much more than $R u$-THA adducts) are excised more efficiently than $R u$-THA complex adducts. This is consistent with the lower binding by RPA to DNA 
containing $R u$-THA adducts and (to a lesser extent) $R u$ CYM/DNA damage [166]. The observation that $R u$-THA was much more cytotoxic than $R u-C Y M$ in both A2780 human ovarian cancer cells and the HT29 colon carcinoma cell line suggests that DNA intercalation has a major role in the cytotoxicity of these DNA-destabilizing derivatives.

In prokaryotes, the NER sensor protein UvrB efficiently recognizes $\mathrm{BaP}$ lesions through lesion-induced local thermodynamic distortion/destabilization and nucleotide flipping [167]. Some variations in the excision efficiency (up to a factor of 3-fold) are observed, depending on the stereoisomeric orientation of the DNA adducts (i.e., $(+)$ or $(-)$, cisor trans-) [121]. In eukaryotes, the $\mathrm{BaP}$ lesions are usually recognized by the NER machinery's "sensor" protein XPC, which then initiates DNA repair in association with the HR23B protein $[168,169]$. In particular, it has been suggested that XPC/HR23B's weaker recognition of (+)-trans$B[a] P-N 2-d G$ adducts (relative to the other conformers) contributes to its higher mutagenic and tumorigenic activity [168]. XPC binding requires DNA bending [170] and is facilitated by local conformational flexibility [143, 144, 171] and destabilization of the base pairing, as evidenced by several model DNA lesions (such as thymine-glycol) [172]. This recognition is driven by the "aromatic sensors" Trp690 and Thp733 [41]. On the cellular level, human bronchial epithelial 16HBE cells treated with $B a P$ (as a source of reactive $B P D E$ ) displayed greater expression of the NER proteins XPA and XPG and the heat shock protein Hsp70. Subcellular analysis with confocal microscopy evidenced nuclear colocalization of Hsp70 with XPA and XPG after $\mathrm{BaP}$ treatment, suggesting that Hsp70 has a role in the cellular DNA repair response [173]. Accordingly, (+/-)-anti-BPDE induces chromosome instability and centromere amplification in lung cells [174]. The cellular consequences of $(+/-)$ anti-BPDE treatment were also assessed using a wholegenome microarray technique in normal human amnion epithelial cells; the researchers observed downregulation of the expression of genes involved in signal transduction, cytoskeleton, DNA repair, metabolism and regulation of transcription and the cell cycle, with features similar to those observed after cell irradiation with UV-light $[175,176]$.

It was recently reported that the structural differences observed for an identical, highly mutagenic, (+)-(7R,8S, 9S,10R)-7,8-dihydroxy-9, 10-epoxy-7,8,9,10-tetrahydrobenzo [a]pyrene-DNA lesion lead to different repair processes as a function to the sequence contexts. Indeed, in cell-free human HeLa extracts, destabilized DNA at a $5^{\prime}-\mathrm{CG}^{*} \mathrm{GC}$ site was more rapidly excised than the bent DNA at a $5^{\prime}-\mathrm{CGG}^{*} \mathrm{C}$ site [125]. Since the DNA helix is already opened up by alkylation, the DNA repair protein recognition step (including induced base flipping) requires less energy and thus is potentially more rapid for DNA that has already been destabilized (at a $5^{\prime}-\mathrm{CG} * \mathrm{GC}$ site) than for bent duplex DNA (the $5^{\prime}-\mathrm{CGG} * \mathrm{C}$ site). This study clearly emphasized the importance of the DNA sequence context for efficient adduct repair [177].

Isomer-dependant DNA repair potency is also assumed to occur with bulky catechol 4-OHEN-adducts, which NER proteins excise with an efficiency that depends on the alkylated base, the stereoisomerism of the adducts and the sequence context. For example, 4-OHEN-dC adducts are more efficiently excised than 4-OHEN-dA adducts [178]. Interestingly, it was shown in male zebrafish that $17 \mathrm{a}$ ethinylestradiol (a source of $4-O H E N$ ) is able to decrease NER efficiency and the expression of NER genes such as XPC, XPA, XPD, and XPF (but not HR23B) [179, 180].

In the search for new cancer drugs with novel mechanisms of action and on the basis of promising preclinical testing, the benzoacronycine derivative S23906-1 has entered Phase I clinical trials as a racemate of two cis-diacetylatedenantiomers. As mentioned above, S23906-1 alkylates DNA in the minor groove and induces strong destabilization of the double helix. Given the presence of two reactive acetate groups on asymmetric carbons, two pairs of enantiomers can be formed: two cis $(1 R ; 2 R$ and $1 S ; 2 S)$ and two trans $(1 R ; 2 S$ and $1 S ; 2 R)$ structures. Hence, $S 23906-1$ is a mixture of $1 R ; 2 R$ and $1 S ; 2 S$. We tested the ability of each of the pure cis-enantiomers not only to react with DNA but also to destabilize the DNA helix and thus affect single-stranded endonuclease activity [181]. Our results showed that DNA destabilization depends on the orientation of the adduct core in the open drug/DNA complex and correlates with differing cellular and antitumour effects: the enantiomer with the greatest DNA destabilization presents the highest antitumour activity in animal models [181].

Little is known about the repair of S23906-1 DNA adducts: the involvement of the NER proteins XPC and CSB was recently found to be related to cell sensitivity to S23906-1, associated with both global genome repair and transcription coupled NER [182].

Ongoing work is seeking to identify the proteins involved in S23906-1/DNA adduct recognition and evaluate their impact on the compound's cytotoxic activity. On one hand, locally destabilized DNA could favour the recognition of a DNA lesion by the DNA repair "sensor" proteins, leading to an increase in the excision efficiency or rate. Full repair after excision thus results in weaker antitumor activity, unless the DNA repair process is blocked-as has been evidenced for the antitumour activity of ET-743 (Yondelis). In this latter case, the ET-743/DNA adduct traps the XPG endonuclease protein involved in the NER machinery and increases the number of single-strand breaks [183]. On the other hand, the wide, local opening of the DNA helix prompted by this particular compound may increase cleavage by singlestrand-specific nuclear endonucleases; the greater number of double-strand breaks may then overwhelm the cancer cells' DNA repair capacity.

\section{Conclusions}

Drug-induced destabilization of the DNA helix appears to be part of a novel antitumour mechanism of action and is associated with particular intercalation processes or postalkylation DNA distortions. DNA-destabilizing compounds are relatively rare and represent just a few drops in an ocean of DNA-interacting molecules (which primarily stabilize the double helix). The molecular and cellular consequences of 
this original binding mode differ from those induced by DNA-stabilizing compounds. In particular, DNA repair and transcription processes are now known to be affected. The DNA replication machinery may also be affected because DNA opening requires less energy when the double helix is already destabilized by a drug. In view of the little available literature data, researchers are now starting to fill in this gap.

Furthermore, we believe that it is important not to consider DNA destabilization as a unique process. This phenomenon must be considered in relation to (i) the potentially associated bend in the DNA helix (as evidenced by the comparison between oxaliplatin- and cisplatin-induced distortions of DNA [151] or the effect of the different isomers of $B P D E[125,177])$, and (ii) the length of the locally destabilized DNA, which varies according to the compound's nature (i.e., the DNA opening induced by benzoacronycine derivatives appears to be extensive enough to be susceptible to single-strand-specific nucleases, whereas other modifications are not) [91]. Recent and ongoing studies of the impact of DNA destabilization on DNA repair and cytotoxicity activities illustrate the increasing need for accurate determination of a potential cancer drug's DNA binding mode and subsequent cellular effects. Moreover, DNA-destabilizing compounds may be associated with different drug-induced resistance processes. Further knowledge of three-dimensional structure activity relationships and the cellular consequences (cytotoxicity, DNA repair processes) of treatment with DNA-destabilizing agents will help to clarify the relevance of cancer drug candidates which stabilize or destabilize the DNA helix and will aid the design of potent antitumour agents.

\section{Acknowledgments}

The authors are grateful to the Ligue Nationale Contre le Cancer (Comité du Nord) and the Institut pour la Recherche sur le Cancer de Lille (IRCL) for Grants (Marie-Hélène David-Cordonnier). They thank the Université de Lille 2/Conseil Régional Nord/Pas-de-Calais for a PhD Fellowship (Gaëlle Lenglet). The authors are grateful to Sabine Depauw for technical expertise.

\section{References}

[1] A. Gilman and F. S. Philips, "The biological actions and therapeutic applications of the B-chloroethyl amines and sulfides," Science, vol. 103, no. 2675, pp. 409-436, 1946.

[2] J. D. Watson and F. H. C. Crick, "Molecular structure of nucleic acids: a structure for deoxyribose nucleic acid," Nature, vol. 171, no. 4356, pp. 737-738, 1953.

[3] M. J. Waring, "DNA modification and cancer," Annual Review of Biochemistry, vol. 50, pp. 159-192, 1981.

[4] B. A. Teicher, Ed., Cancer Therapeutics: Experimental and Clinical Agents (Cancer Drug Discovery and Development) [Hardcover], Humana Press, Clifton, NJ, USA, 1st edition, 1996.

[5] M. F. Braña, M. Cacho, A. Gradillas, B. de Pascual-Teresa, and A. Ramos, "Intercalators as anticancer drugs," Current Pharmaceutical Design, vol. 7, no. 17, pp. 1745-1780, 2001.
[6] I. Kostova, "Platinum complexes as anticancer agents," Recent Patents on Anti-Cancer Drug Discovery, vol. 1, no. 1, pp. 1-22, 2006.

[7] I. Kostova, "Ruthenium complexes as anticancer agents," Current Medicinal Chemistry, vol. 13, no. 9, pp. 1085-1107, 2006.

[8] U. Dornberger, M. Leijon, and H. Fritzsche, "High base pair opening rates in tracts of GC base pairs," The Journal of Biological Chemistry, vol. 274, no. 11, pp. 6957-6962, 1999.

[9] J. Bode, S. Winkelmann, S. Götze et al., "Correlations between scaffold/matrix attachment region (S/MAR) binding activity and DNA duplex destabilization energy," Journal of Molecular Biology, vol. 358, no. 2, pp. 597-613, 2006.

[10] T. D. Schneider, "Strong minor groove base conservation in sequence logos implies DNA distortion or base flipping during replication and transcription initiation," Nucleic Acids Research, vol. 29, no. 23, pp. 4881-4891, 2001.

[11] C. H. Choi, G. Kalosakas, K. $\varnothing$. Rasmussen, M. Hiromura, A. R. Bishop, and A. Usheva, "DNA dynamically directs its own transcription initiation," Nucleic Acids Research, vol. 32, no. 4, pp. 1584-1590, 2004.

[12] M. Gniazdowski, W. A. Denny, S. M. Nelson, and M. Czyz, "Effects of anticancer drugs on transcription factor-DNA interactions," Expert Opinion on Therapeutic Targets, vol. 9, no. 3, pp. 471-489, 2005.

[13] C. R. Calladine and H.R. Drew, Understanding DNA: The Molecule and How It Works, Academic Press, San Diego, Calif, USA, 2nd edition, 1997.

[14] B. F. Putnam, L. L. Van Zandt, E. W. Prohofsky, and W. N. Mei, "Resonant and localized breathing modes in terminal regions of the DNA double helix," Biophysical Journal, vol. 35, no. 2, pp. 271-287, 1981.

[15] S. C. Harvey, "DNA structural dynamics: iongitudinal breathing as a possible mechanism for the B $\rightleftarrows \mathrm{Z}$ transition," Nucleic Acids Research, vol. 11, no. 14, pp. 4867-4878, 1983.

[16] D. R. Kearns, "NMR studies of conformational states and dynamics of DNA," CRC Critical Reviews in Biochemistry, vol. 15, no. 3, pp. 237-290, 1984.

[17] K. J. Breslauer, R. Frank, H. Blocker, and L. A. Marky, "Predicting DNA duplex stability from the base sequence," Proceedings of the National Academy of Sciences of the United States of America, vol. 83, no. 11, pp. 3746-3750, 1986.

[18] R. Beger, Y. Feng, and E. W. Prohofsky, "Vibrational fluctuations of hydrogen bonds in a DNA double helix with alternating TA type inserts," Biophysical Journal, vol. 58, no. 2, pp. 437-445, 1990.

[19] C. J. Benham, "Energetics of the strand separation transition in superhelical DNA," Journal of Molecular Biology, vol. 225, no. 3, pp. 835-847, 1992.

[20] C. J. Benham, "Sites of predicted stress-induced DNA duplex destabilization occur preferentially at regulatory loci," Proceedings of the National Academy of Sciences of the United States of America, vol. 90, no. 7, pp. 2999-3003, 1993.

[21] C. J. Benham, "Duplex destabilization in superhelical DNA is predicted to occur at specific transcriptional regulatory regions," Journal of Molecular Biology, vol. 255, no. 3, pp. 425-434, 1996.

[22] Y. Z. Chen and E. W. Prohofsky, "Sequence and temperature dependence of the interbase hydrogen-bond breathing modes in B-DNA polymers: comparison with low-frequency Raman peaks and their role in helix melting," Biopolymers, vol. 35 , no. 6, pp. 573-582, 1995. 
[23] A. G. Pedersen, P. Baldi, Y. Chauvin, and S. Brunak, "The biology of eukaryotic promoter prediction-a review," Computers and Chemistry, vol. 23, no. 3-4, pp. 191-207, 1999.

[24] F. Lankaš, J. Šponer, P. Hobza, and J. Langowski, "Sequencedependent elastic properties of DNA," Journal of Molecular Biology, vol. 299, no. 3, pp. 695-709, 2000.

[25] S. Wärmländer, J. E. Sponer, J. Sponer, and M. Leijoni, “The influence of the thymine C5 methyl group on spontaneous base pair breathing in DNA," The Journal of Biological Chemistry, vol. 277, no. 32, pp. 28491-28497, 2002.

[26] A. Krueger, E. Protozanova, and M. D. Frank-Kamenetskii, "Sequence-dependent basepair opening in DNA double helix," Biophysical Journal, vol. 90, no. 9, pp. 3091-3099, 2006.

[27] T. Ambjörnsson, S. K. Banik, O. Krichevsky, and R. Metzler, "Sequence sensitivity of breathing dynamics in heteropolymer DNA," Physical Review Letters, vol. 97, no. 12, Article ID 128105, 4 pages, 2006.

[28] T. Ambjörnsson, S. K. Banik, O. Krichevsky, and R. Metzler, "Breathing dynamics in heteropolymer DNA," Biophysical Journal, vol. 92, no. 8, pp. 2674-2684, 2007.

[29] C. A. S.A. Minetti, D. P. Remeta, R. Dickstein, and K. J. Breslauer, "Energetic signatures of single base bulges: thermodynamic consequences and biological implications," Nucleic Acids Research, vol. 38, no. 1, pp. 97-116, 2010.

[30] Y.-J. Li, X.-H. Fu, D.-P. Liu, and C.-C. Liang, "Opening the chromatin for transcription," International Journal of Biochemistry and Cell Biology, vol. 36, no. 8, pp. 1411-1423, 2004.

[31] M. D. Betterton and F. Jülicher, "Opening of nucleic-acid double strands by helicases: active versus passive opening," Physical Review E, vol. 71, no. 1, Article ID 011904, 11 pages, 2005.

[32] S. Schuck and A. Stenlund, "ATP-dependent minor groove recognition of TA base pairs is required for template melting by the E1 initiator protein," Journal of Virology, vol. 81, no. 7, pp. 3293-3302, 2007.

[33] C. M. Sanders, "A DNA-binding activity in BPV initiator protein E1 required for melting duplex ori DNA but not processive helicase activity initiated on partially singlestranded DNA," Nucleic Acids Research, vol. 36, no. 6, pp. 1891-1899, 2008.

[34] F. Jelen and E. Palecek, "Nucleotide sequence-dependent opening of double-stranded DNA at an electrically charged surface," General Physiology and Biophysics, vol. 4, no. 2, pp. 219-237, 1985.

[35] T. T. Eckdahl and J. N. Anderson, "Conserved DNA structures in origins of replication," Nucleic Acids Research, vol. 18, no. 6, pp. 1609-1612, 1990.

[36] B. Essevaz-Roulet, U. Bockelmann, and F. Heslot, "Mechanical separation of the complementary strands of DNA," Proceedings of the National Academy of Sciences of the United States of America, vol. 94, no. 22, pp. 11935-11940, 1997.

[37] T. M. Lohman and K. P. Bjornson, "Mechanisms of helicasecatalyzed DNA unwinding," Annual Review of Biochemistry, vol. 65, pp. 169-214, 1996.

[38] M. Gyimesi, K. Sarlós, and M. Kovács, "Processive translocation mechanism of the human Bloom's syndrome helicase along single-stranded DNA," Nucleic Acids Research, 2010.

[39] M. S. Wold, "Replication protein A: a heterotrimeric, singlestranded DNA-binding protein required for eukaryotic DNA metabolism," Annual Review of Biochemistry, vol. 66, pp. 6192, 1997.
[40] S. Waga and B. Stillman, "The DNA replication fork in eukaryotic cells," Annual Review of Biochemistry, vol. 67, pp. 721-751, 1998.

[41] O. Maillard, S. Solyom, and H. Naegeli, "An aromatic sensor with aversion to damaged strands confers versatility to DNA repair," PLoS Biology, vol. 5, no. 4, article e79, 2007.

[42] G. Herrick and B. Alberts, "Nucleic acid helix coil transitions mediated by helix unwinding proteins from calf thymus," The Journal of Biological Chemistry, vol. 251, no. 7, pp. 21332141, 1976.

[43] S. R. Planck and S. H. Wilson, "Studies on the structure of mouse helix-destabilizing protein-1. DNA binding and controlled proteolysis with trypsin," The Journal of Biological Chemistry, vol. 255, no. 23, pp. 11547-11556, 1980.

[44] R. L. Karpel and A. C. Burchard, "A basic isozyme of yeast glyceraldehyde-3-phosphate dehydrogenase with nucleic acid helix-destabilizing activity," Biochimica et Biophysica Acta, vol. 654, no. 2, pp. 256-267, 1981.

[45] K. Javaherian, M. Sadeghi, and L. F. Liu, "Nonhistone proteins HMG1 and HMG2 unwind DNA double helix," Nucleic Acids Research, vol. 6, no. 11, pp. 3569-3580, 1979.

[46] A. P. Butler, J. K. W. Mardian, and D. E. Olins, "Nonhistone chromosomal protein HMG 1 interactions with DNA: fluorescence and thermal denaturation studies," The Journal of Biological Chemistry, vol. 260, no. 19, pp. 10613-10620, 1985.

[47] M.-H. David-Cordonnier, M. Hamdane, C. Bailly, and J.C. D'Halluin, "The DNA binding domain of the human cAbl tyrosine kinase preferentially binds to DNA sequences containing an AAC motif and to distorted DNA structures," Biochemistry, vol. 37, no. 17, pp. 6065-6076, 1998.

[48] M.-H. David-Cordonnier, D. Payet, J.-C. D’Halluin, M. J. Waring, A. A. Travers, and C. Bailly, "The DNA-binding domain of human c-Abl tyrosine kinase promotes the interaction of a HMG chromosomal protein with DNA," Nucleic Acids Research, vol. 27, no. 11, pp. 2265-2270, 1999.

[49] M. J. Heath, S. S. Derebail, R. J. Gorelick, and J. J. DeStefano, "Differing roles of the $\mathrm{N}$ - and C-terminal zinc fingers in human immunodeficiency virus nucleocapsid proteinenhanced nucleic acid annealing," The Journal of Biological Chemistry, vol. 278, no. 33, pp. 30755-30763, 2003.

[50] H. Wang, Y.-S. Yeh, and P. F. Barbara, "HIV-1 nucleocapsid protein bends double-stranded nucleic acids," Journal of the American Chemical Society, vol. 131, no. 42, pp. 1553415543, 2009.

[51] N. Narayanan, R. J. Gorelick, and J. J. DeStefano, "Structure/function mapping of amino acids in the N-terminal zinc finger of the human immunodeficiency virus type 1 nucleocapsid protein: residues responsible for nucleic acid helix destabilizing activity," Biochemistry, vol. 45, no. 41, pp. 12617-12628, 2006.

[52] A. Bera, A.-C. Roche, and P. K. Nandi, "Bending and unwinding of nucleic acid by prion protein," Biochemistry, vol. 46, no. 5, pp. 1320-1328, 2007.

[53] D. P. Hornby and G. C. Ford, "Protein-mediated base flipping," Current Opinion in Biotechnology, vol. 9, no. 4, pp. 354-358, 1998.

[54] C. Cao, Y. L. Jiang, J. T. Stivers, and F. Song, "Dynamic opening of DNA during the enzymatic search for a damaged base," Nature structural \& Molecular Biology, vol. 11, no. 12, pp. 1230-1236, 2004.

[55] E. Malta, G. F. Moolenaar, and N. Goosen, "Base flipping in nucleotide excision repair," The Journal of Biological Chemistry, vol. 281, no. 4, pp. 2184-2194, 2006. 
[56] D. J. Hosfield, Y. Guan, B. J. Haas, R. P. Cunningham, and J. A. Tainer, "Structure of the DNA repair enzyme endonuclease IV and its DNA complex: double-nucleotide flipping at abasic sites and three-metal-ion catalysis," Cell, vol. 98, no. 3, pp. 397-408, 1999.

[57] S. R. W. Bellamy, K. Krusong, and G. S. Baldwin, "A rapid reaction analysis of uracil DNA glycosylase indicates an active mechanism of base flipping," Nucleic Acids Research, vol. 35, no. 5, pp. 1478-1487, 2007.

[58] J. L. Tubbs, A. E. Pegg, and J. A. Tainer, "DNA binding, nucleotide flipping, and the helix-turn-helix motif in base repair by O6-alkylguanine-DNA alkyltransferase and its implications for cancer chemotherapy," DNA Repair, vol. 6, no. 8, pp. 1100-1115, 2007.

[59] E. Malta, C. P. Verhagen, G. F. Moolenaar, D. V. Filippov, G. A. Van der Marel, and N. Goosen, "Functions of base flipping in E. coli nucleotide excision repair," DNA Repair, vol. 7, no. 10, pp. 1647-1658, 2008.

[60] C.-G. Yang, C. Yi, E. M. Duguid, et al., "Crystal structures of DNA/RNA repair enzymes $\mathrm{AlkB}$ and $\mathrm{ABH} 2$ bound to dsDNA," Nature, vol. 452, no. 7190, pp. 961-965, 2008.

[61] S. Jiranusornkul and C. A. Laughton, "Destabilization of DNA duplexes by oxidative damage at guanine: implications for lesion recognition and repair," Journal of the Royal Society, vol. 5, supplement 3, pp. 191-198, 2008.

[62] P. M. Vertino, "Structures and functions," in $S$ Adenosylmethionine-dependent methyltransferases, X. Cheng and R. M. Blumenthal, Eds., pp. 341-372, 1999.

[63] O. Sundheim, V. A. Talstad, C. B. Vågbø, G. Slupphaug, and H. E. Krokan, "AlkB demethylases flip out in different ways," DNA Repair, vol. 7, no. 11, pp. 1916-1923, 2008.

[64] N. Huang and A. D. MacKerell Jr., "Atomistic view of base flipping in DNA," Philosophical Transactions of the Royal Society A, vol. 362, no. 1820, pp. 1439-1460, 2004.

[65] K. Arita, M. Ariyoshi, H. Tochio, Y. Nakamura, and M. Shirakawa, "Recognition of hemi-methylated DNA by the SRA protein UHRF1 by a base-flipping mechanism," Nature, vol. 455, no. 7214, pp. 818-821, 2008.

[66] H. Hashimoto, J. R. Horton, X. Zhang, M. Bostick, S. E. Jacobsen, and X. Cheng, "The SRA domain of UHRF1 flips 5-methylcytosine out of the DNA helix," Nature, vol. 455, no. 7214, pp. 826-829, 2008.

[67] C. Mura and J. A. McCammon, "Molecular dynamics of a $\kappa \mathrm{B}$ DNA element: base flipping via cross-strand intercalative stacking in a microsecond-scale simulation," Nucleic Acids Research, vol. 36, no. 15, pp. 4941-4955, 2008.

[68] V. Kleinwächter, Z. Balcarová, and J. Boháček, “Thermal stability of complexes of diaminoacridines with deoxyribonucleic acids of varying base content," Biochimica et Biophysica Acta, vol. 174, no. 1, pp. 188-201, 1969.

[69] J. Kapuscinski and Z. Darzynkiewicz, "Increased accessibility of bases in DNA upon binding of acridine orange," Nucleic Acids Research, vol. 11, no. 21, pp. 7555-7568, 1983.

[70] J. Kapuscinski and Z. Darzynkiewicz, "Denaturation of nucleic acids induced by intercalating agents. Biochemical and biophysical properties of acridine orange-DNA complexes," Journal of Biomolecular Structure and Dynamics, vol. 1, no. 6, pp. 1485-1499, 1984.

[71] Z. Darzynkiewicz, D. Evenson, J. Kapuscinski, and M. R. Melamed, "Denaturation of RNA and DNA in situ induced by acridine orange," Experimental Cell Research, vol. 148, no. 1, pp. 31-46, 1983.
[72] Z. Darzynkiewicz, F. Traganos, J. Kapuscinski, and M. R. Melamed, "Denaturation and condensation of DNA in situ induced by acridine orange in relation to chromatin changes during growth and differentiation of Friend erythroleukemia cells," Cytometry, vol. 6, no. 3, pp. 195-207, 1985.

[73] A. Canals, M. Purciolas, J. Aymamí, and M. Coll, "The anticancer agent ellipticine unwinds DNA by intercalative binding in an orientation parallel to base pairs," Acta Crystallographica Section D, vol. 61, no. 7, pp. 1009-1012, 2005.

[74] M. Cirilli, F. Bachechi, G. Ughetto, F. P. Colonna, and M. L. Capobianco, "Interactions between morpholinyl anthracyclines and DNA. The crystal structure of a morpholino doxorubicin bound to d(CGTACG)," Journal of Molecular Biology, vol. 230, no. 3, pp. 878-889, 1993.

[75] N. C. Garbett and D. E. Graves, "Extending nature's leads: the anticancer agent ellipticine," Current Medicinal ChemistryAnti-Cancer Agents, vol. 4, no. 2, pp. 149-172, 2004.

[76] F. Zunino, R. Gambetta, A. Di Marco, and A. Zaccara, "Interaction of daunomycin and its derivatives with DNA," Biochimica et Biophysica Acta, vol. 277, no. 3, pp. 489-498, 1972.

[77] K. W. Kohn, M. J. Waring, D. Glaubiger, and C. A. Friedman, "Intercalative binding of ellipticine to DNA," Cancer Research, vol. 35, no. 1, pp. 71-76, 1975.

[78] M. J. Waring, "Structural requirements for the binding of ethidium to nucleic acids," Biochimica et Biophysica Acta, vol. 114, no. 2, pp. 234-244, 1966.

[79] M. P. Teulade-Fichou, J. P. Vigneron, and J. M. Lehn, "Molecular recognition of nucleosides and nucleotides by a water soluble cyclo-bis-intercaland type receptor molecule based on acridine subunits," Supramolecular Chemistry, vol. 5, pp. 139-147, 1995.

[80] A. Slama-Schwok, M.-P. Teulade-Fichou, J.-P. Vigneron, E. Taillandier, and J.-M. Lehn, "Selective binding of a macrocyclic bis-acridine to DNA hairpins," Journal of the American Chemical Society, vol. 117, no. 26, pp. 6822-6830, 1995.

[81] A. Slama-Schwok, F. Peronnet, E. Hantz-Brachet et al., "A macrocyclic bis-acridine shifts the equilibrium from duplexes towards DNA hairpins," Nucleic Acids Research, vol. 25, no. 13, pp. 2574-2581, 1997.

[82] A. J. Blacker, M.-P. Teulade-Fichou, J.-P. Vigneron, M. Fauquet, and J.-M. Lehn, "Selective photocleavage of singlestranded nucleic acids by cyclobisintercaland molecules," Bioorganic and Medicinal Chemistry Letters, vol. 8, no. 6, pp. 601-606, 1998.

[83] M. Jourdan, J. García, J. Lhomme, M.-P. Teulade-Fichou, J.P. Vigneron, and J.-M. Lehn, "Threading bis-intercalation of a macrocyclic bisacridine at abasic sites in DNA: nuclear magnetic resonance and molecular modeling study," Biochemistry, vol. 38, no. 43, pp. 14205-14213, 1999.

[84] A. David, N. Bleimling, C. Beuck, J.-M. Lehn, E. Weinhold, and M.-P. Teulade-Fichou, "DNA mismatch-specific base flipping by a bisacridine macrocycle," ChemBioChem, vol. 4, no. 12, pp. 1326-1331, 2003.

[85] Y.-B. Shi and J. E. Hearst, "Thermostability of doublestranded deoxyribonucleic acids: effects of covalent additions of a psoralen," Biochemistry, vol. 25, no. 20, pp. 5895-5902, 1986.

[86] M. Tomasz, A. K. Chawla, and R. Lipman, "Mechanism of monofunctional and bifunctional alkylation of DNA by mitomycin C," Biochemistry, vol. 27, no. 9, pp. 3182-3187, 1988. 
[87] A. K. Basu, C. J. Hanrahan, S. A. Malia, S. Kumar, R. Bizanek, and M. Tomasz, "Effect of site-specifically located mitomycin C-DNA monoadducts on in vitro DNA synthesis by DNA polymerases," Biochemistry, vol. 32, no. 18, pp. 4708-4718, 1993.

[88] A. J. Warren, A. E. Maccubbin, and J. W. Hamilton, "Detection of mitomycin C-DNA adducts in vivo by 32Ppostlabeling: time course for formation and removal of adducts and biochemical modulation," Cancer Research, vol. 58, no. 3, pp. 453-461, 1998.

[89] J. Kašpárková, O. Nováková, O. Vrána, N. Farrell, and V. Brabec, "Effect of geometric isomerism in dinuclear platinum antitumor complexes on DNA interstrand crosslinking," Biochemistry, vol. 38, no. 34, pp. 10997-11005, 1999.

[90] A. S. Fridman, V. Brabec, S. G. Haroutiunian, R. M. Wartell, and D. Y. Lando, "Melting of cross-linked DNA v. crosslinking effect caused by local stabilization of the double helix," Journal of Biomolecular Structure and Dynamics, vol. 20, no. 4, pp. 533-545, 2003.

[91] M.-H. David-Cordonnier, W. Laine, A. Lansiaux et al., "Covalent binding of antitumor benzoacronycines to doublestranded DNA induces helix opening and the formation of single-stranded DNA: unique consequences of a novel DNAbonding mechanism," Molecular Cancer Therapeutics, vol. 4, no. 1, pp. 71-80, 2005.

[92] A. Gelasco and S. J. Lippard, "NMR solution structure of a DNA dodecamer duplex containing a cisdiammineplatinum(II) $\mathrm{d}(\mathrm{GpG})$ intrastrand cross-link, the major adduct of the anticancer drug cisplatin," Biochemistry, vol. 37, no. 26, pp. 9230-9239, 1998.

[93] M. L. G. Dronkert and R. Kanaar, "Repair of DNA interstrand cross-links," Mutation Research, vol. 486, no. 4, pp. 217-247, 2001.

[94] O. D. Schärer, "A molecular basis for damage recognition in eukaryotic nucleotide excision repair," ChemBioChem, vol. 9, no. 1, pp. 21-23, 2008.

[95] D. M. Noll, T. M. Mason, and P. S. Miller, "Formation and repair of interstrand cross-links in DNA," Chemical Reviews, vol. 106, no. 2, pp. 277-301, 2006.

[96] S. F. Bellon, J. H. Coleman, and S. J. Lippard, "DNA unwinding produced by site-specific intrastrand cross-links of the antitumor drug cis-diamminedichloroplatinum(II)," Biochemistry, vol. 30, no. 32, pp. 8026-8035, 1991.

[97] V. Brabec, J. Reedijk, and M. Leng, "Sequence-dependent distortions induced in DNA by monofunctional platinum(II) binding," Biochemistry, vol. 31, no. 49, pp. 12397-12402, 1992.

[98] J.-M. Malinge, C. Pérez, and M. Leng, "Base sequenceindependent distorsions induced by interstrand crosslinks in cis-diamminedichloroplatinum (II)-modified DNA," Nucleic Acids Research, vol. 22, no. 19, pp. 3834-3839, 1994.

[99] J.-M. Malinge, M.-J. Giraud-Panis, and M. Leng, "Interstrand cross-links of cisplatin induce striking distortions in DNA," Journal of Inorganic Biochemistry, vol. 77, no. 1-2, pp. 23-29, 1999.

[100] F. Coste, J.-M. Malinge, L. Serre et al., "Crystal structure of a double-stranded DNA containing a cisplatin interstrand cross-link at $1.63 \AA$ resolution: hydration at the platinated site," Nucleic Acids Research, vol. 27, no. 8, pp. 1837-1846, 1999.
[101] J. Kasparkova, V. Marini, V. Bursova, and V. Brabec, "Biophysical studies on the stability of DNA intrastrand crosslinks of transplatin," Biophysical Journal, vol. 95, no. 9, pp. 4361-4371, 2008.

[102] A. S. Fridman, E. N. Galyuk, V. I. Vorob'ev, A. N. Skvortsov, and D. Y. Lando, "Melting of crosslinked DNA: VI. Comparison of influence of interstrand crosslinks and other chemical modifications formed by antitumor compounds on DNA stability," Journal of Biomolecular Structure and Dynamics, vol. 26, no. 2, pp. 175-185, 2008.

[103] N. Poklar, D. S. Pilch, S. J. Lippard, E. A. Redding, S. U. Dunham, and K. J. Breslauer, "Influence of cisplatin intrastrand crosslinking on the conformation, thermal stability, and energetics of a 20-mer DNA duplex," Proceedings of the National Academy of Sciences of the United States of America, vol. 93, no. 15, pp. 7606-7611, 1996.

[104] D. S. Pilch, S. U. Dunham, E. R. Jamieson, S. J. Lippard, and K. J. Breslauer, "DNA sequence context modulates the impact of a cisplatin 1,2-d(GpG) intrastrand cross-link on the conformational and thermodynamic properties of duplex DNA," Journal of Molecular Biology, vol. 296, no. 3, pp. 803$812,2000$.

[105] J. Malina, O. Nováková, M. Vojtiskova, G. Natile, and V. Brabec, "Conformation of DNA GG intrastrand crosslink of antitumor oxaliplatin and its enantiomeric analog," Biophysical Journal, vol. 93, no. 11, pp. 3950-3962, 2007.

[106] E. N. Galyuk, A. S. Fridman, V. I. Vorob'ev et al., "Compensation of DNA stabilization and destabilization effects caused by cisplatin is partially disturbed in alkaline medium," Journal of Biomolecular Structure and Dynamics, vol. 25, no. 4, pp. 407-417, 2008.

[107] V. Brabec, M. Sip, and M. Leng, "DNA conformational change produced by the site-specific interstrand cross- link of trans-diamminedichloroplatinum(II)," Biochemistry, vol. 32, no. 43, pp. 11676-11681, 1993.

[108] S. Teletchéa, S. Komeda, J.-M. Teuben, M.-A. ElizondoRiojas, J. Reedijk, and J. Kozelka, "A pyrazolato-bridged dinuclear platinum(II) complex induces only minor distortions upon DNA-binding," Chemistry - A European Journal, vol. 12, no. 14, pp. 3741-3753, 2006.

[109] V. Bursova, J. Kasparkova, C. Hofr, and V. Brabec, "Effects of monofunctional adducts of platinum(II) complexes on thermodynamic stability and energetics of DNA duplexes," Biophysical Journal, vol. 88, no. 2, pp. 1207-1214, 2005.

[110] A. Schwartz, L. Marrot, and M. Leng, "Conformation of DNA modified at a $\mathrm{d}(\mathrm{GG})$ or a $\mathrm{d}(\mathrm{AG})$ site by the antitumor drug cis-diamminedichloroplatinum(II)," Biochemistry, vol. 28, no. 20, pp. 7975-7979, 1989.

[111] M. Hägerlöf, P. Papsai, C. S. Chow, and S. K. C. Elmroth, "More pronounced salt dependence and higher reactivity for platination of the hairpin r(CGCGUUGUUCGCG) compared with d(CGCGTTGTTCGCG)," Journal of Biological Inorganic Chemistry, vol. 11, no. 8, pp. 974-990, 2006.

[112] G. Sava, S. Pacor, F. Bregant, V. Ceschia, and G. Mestroni, "Metal complexes of ruthenium: antineoplastic properties and perspectives," Anti-Cancer Drugs, vol. 1, no. 2, pp. 99108, 1990.

[113] G. Sava, S. Pacor, F. Bregant, and V. Ceschia, "Metal complexes of ruthenium: a potential class of selective anticancer drugs," Anticancer Research, vol. 11, no. 3, pp. 1103-1107, 1991.

[114] C. X. Zhang and S. J. Lippard, "New metal complexes as potential therapeutics," Current Opinion in Chemical Biology, vol. 7, no. 4, pp. 481-489, 2003. 
[115] O. Nováková, H. Chen, O. Vrana, A. Rodger, P. J. Sadler, and V. Brabec, "DNA interactions of monofunctional organometallic ruthenium(II) antitumor complexes in cellfree media," Biochemistry, vol. 42, no. 39, pp. 11544-11554, 2003.

[116] O. Nováková, A. A. Nazarov, C. G. Hartinger, B. K. Keppler, and V. Brabec, "DNA interactions of dinuclear RuII arene antitumor complexes in cell-free media," Biochemical Pharmacology, vol. 77, no. 3, pp. 364-374, 2009.

[117] O. Nováková, J. Malina, T. Suchankova, et al., "Energetics, conformation, and recognition of DNA duplexes modified by monodentate $\mathrm{Ru}(\mathrm{II})$ complexes containing terphenyl arenes," Chemistry - A European Journal, vol. 16, no. 19, pp. 57445754, 2010.

[118] H. P. Spielmann, T. J. Dwyer, J. E. Hearst, and D. E. Wemmer, "Solution structures of psoralen monoadducted and crosslinked DNA oligomers by NMR spectroscopy and restrained molecular dynamics," Biochemistry, vol. 34, no. 40, pp. 12937-12953, 1995.

[119] N. Zhang, C. Lin, X. Huang et al., "Methylation of cytosine at $\mathrm{C} 5$ in a $\mathrm{CpG}$ sequence context causes a conformational switch of a benzo[a]pyrene diol epoxide-N2-guanine adduct in DNA from a minor groove alignment to intercalation with base displacement," Journal of Molecular Biology, vol. 346, no. 4, pp. 951-965, 2005.

[120] Y. Zou and B. Van Houten, "Strand opening by the UvrA(2)B complex allows dynamic recognition of DNA damage," The EMBO Journal, vol. 18, pp. 4889-4901, 1999.

[121] Y. Zou, C. Luo, and N. E. Geacintov, "Hierarchy of DNA damage recognition in Escherichia coli nucleotide excision repair," Biochemistry, vol. 40, no. 9, pp. 2923-2931, 2001.

[122] M. Cosman, C. De los Santos, R. Fiala, et al., "Solution conformation of the major adduct between the carcinogen (+)-anti-benzo[a]pyrene diol epoxide and DNA," Proceedings of the National Academy of Sciences of the United States of America, vol. 89, no. 5, pp. 1914-1918, 1992.

[123] M. Cosman, C. De Los Santos, R. Fiala et al., "Solution conformation of the (+)-cis-anti-[BP]dG adduct in a DNA duplex: intercalation of the covalently attached benzo[a]pyrenyl ring into the helix and displacement of the modified deoxyguanosine," Biochemistry, vol. 32, no. 16, pp. 4145-4155, 1993.

[124] F. A. Rodríguez, Y. Cai, C. Lin et al., "Exocyclic amino groups of flanking guanines govern sequence-dependent adduct conformations and local structural distortions for minor groove-aligned benzo $[\alpha]$ pyrenyl-guanine lesions in a GG mutation hotspot context," Nucleic Acids Research, vol. 35, no. 5, pp. 1555-1568, 2007.

[125] K. Kropachev, M. Kolbanovskii, Y. Cai et al., "The sequence dependence of human nucleotide excision repair efficiencies of benzo[a]pyrene-derived DNA lesions: insights into the structural factors that favor dual incisions," Journal of Molecular Biology, vol. 386, no. 5, pp. 1193-1203, 2009.

[126] J. L. Bolton, E. Pisha, F. Zhang, and S. Qiu, "Role of quinoids in estrogen carcinogenesis," Chemical Research in Toxicology, vol. 11, no. 10, pp. 1113-1127, 1998.

[127] J. L. Bolton, "Quinoids, quinoid radicals, and phenoxyl radicals formed from estrogens and antiestrogens," Toxicology, vol. 177, no. 1, pp. 55-65, 2002.

[128] J. E. Rossouw, G. L. Anderson, R. L. Prentice et al., "Risks and benefits of estrogen plus progestin in healthy postmenopausal women: principal results from the women's health initiative randomized controlled trial," Journal of the American Medical Association, vol. 288, no. 3, pp. 321-333, 2002.

[129] F. Zhang, Y. Chen, E. Pisha, et al., "The major metabolite of equilin, 4-Hydroxyequilin, autoxidizes to an oquinone which isomerizes to the potent cytotoxin 4Hydroxyequilenin-o-quinone," Chemical Research in Toxicology, vol. 12, no. 2, pp. 204-213, 1999.

[130] E. Pisha, X. Lui, A. I. Constantinou, and J. L. Bolton, "Evidence that a metabolilte of equine estrogens, 4hydroxyequilenin, induces cellular transformation in vitro," Chemical Research in Toxicology, vol. 14, no. 1, pp. 82-90, 2001.

[131] L. Shen, S. Qiu, Y. Chen et al., "Alkylation of 2'deoxynucleosides and DNA by the premarin metabolite 4hydroxyequilenin semiquinone radical," Chemical Research in Toxicology, vol. 11, no. 2, pp. 94-101, 1998.

[132] F. Zhang, S. M. Swanson, R. B. Van Breemen et al., "Equine estrogen metabolite 4-hydroxyequilenin induces DNA damage in the rat mammary tissues: formation of single-strand breaks, apurinic sites, stable adducts, and oxidized bases," Chemical Research in Toxicology, vol. 14, no. 12, pp. 16541659, 2001.

[133] J. Embrechts, F. Lemire, W. Van Dongen, and E. L. Esmans, "Equilenin-2'-deoxynucleoside adducts: analysis with nanoliquid chromatography coupled to nano-electrospray tandem mass spectrometry," Journal of Mass Spectrometry, vol. 36, no. 3, pp. 317-328, 2001.

[134] A. Kolbanovskiy, V. Kuzmin, A. Shastry et al., "Base selectivity and effects of sequence and DNA secondary structure on the formation of covalent adducts derived from the equine estrogen metabolite 4-hydroxyequilenin," Chemical Research in Toxicology, vol. 18, no. 11, pp. 1737-1747, 2005.

[135] J. Embrechts, F. Lemière, W. Van Dongen et al., "Detection of estrogen DNA-adducts in human breast tumor tissue and healthy tissue by combined nano LC-nano ES tandem mass spectrometry," Journal of the American Society for Mass Spectrometry, vol. 14, no. 5, pp. 482-491, 2003.

[136] S. Ding, R. Shapiro, N. E. Geacintov, and S. Broyde, "4Hydroxyequilenin-adenine lesions in DNA duplexes: sereochemistry, damage site, and structure," Biochemistry, vol. 46, no. 1, pp. 182-191, 2007.

[137] S. Ding, R. Shapiro, Y. Cai, N. E. Geacintov, and S. Broyde, "Conformational properties of equilenin-DNA adducts: stereoisomer and base effects," Chemical Research in Toxicology, vol. 21, no. 5, pp. 1064-1073, 2008.

[138] S. Ding, Y. Wang, A. Kolbanovskiy, et al., "Determination of absolute configurations of 4-hydroxyequilenin-cytosine and -adenine adducts by optical rotatory dispersion, electronic circular dichroism, density functional theory calculations, and mass spectrometry," Chemical Research in Toxicology, vol. 21, no. 9, pp. 1739-1748, 2008.

[139] S. Ding, R. Shapiro, N. E. Geacintov, and S. Broyde, "Equilenin-derived DNA adducts to cytosine in DNA duplexes: structures and thermodynamics," Biochemistry, vol. 44, no. 44, pp. 14565-14576, 2005.

[140] Y. Pommier, G. Kohlhagen, C. Bailly, M. Waring, A. Mazumder, and K. W. Kohn, "DNA sequence- and structureselective alkylation of guanine N2 in the DNA minor groove by ecteinascidin 743 , a potent antitumor compound from the caribbean tunicate Ecteinascidia turbinata," Biochemistry, vol. 35, no. 41, pp. 13303-13309, 1996. 
[141] M. Tomasz, A. Das, K. S. Tang et al., "The purine 2amino group as the critical recognition element for sequencespecific alkylation and cross-linking of DNA by mitomycin C," Journal of the American Chemical Society, vol. 120, no. 45, pp. 11581-11593, 1998.

[142] D. E. Thurston, in Molecular Aspects of Anticancer Drug-DNA Interactions, S. Neidle and M. J. Waring, Eds., vol. 1, pp. 5487, Macmillan, London, UK, 1999.

[143] R. J. Isaacs and H. P. Spielmann, "A model for initial DNA lesion recognition by NER and MMR based on local conformational flexibility," DNA Repair, vol. 3, no. 5, pp. 455-464, 2004.

[144] O. D. Schärer, "A molecular basis for damage recognition in eukaryotic nucleotide excision repair," ChemBioChem, vol. 9, no. 1, pp. 21-23, 2008.

[145] J. L. Tubbs, V. Latypov, S. Kanugula, et al., "Flipping of alkylated DNA damage bridges base and nucleotide excision repair," Nature, vol. 459, no. 7248, pp. 808-813, 2009.

[146] V. Brabec, "DNA Modifications by antitumor platinum and ruthenium compounds: their recognition and repair," Progress in Nucleic Acid Research and Molecular Biology, vol. 71, pp. 1-68, 2002.

[147] V. Brabec and O. Nováková, "DNA binding mode of ruthenium complexes and relationship to tumor cell toxicity," Drug Resistance Updates, vol. 9, no. 3, pp. 111-122, 2006.

[148] T. Bugarcic, O. Nováková, A. Halámiková, et al., "Cytotoxicity, cellular uptake, and DNA interactions of new monodentate ruthenium(II) complexes containing terphenyl arenes," Journal of Medicinal Chemistry, vol. 51, no. 17, pp. 5310-5319, 2008.

[149] R. Reeves and J. E. Adair, "Role of high mobility group (HMG) chromatin proteins in DNA repair," DNA Repair, vol. 4, no. 8, pp. 926-938, 2005.

[150] P. L. Privalov, A. I. Dragan, and C. Crane-Robinson, "The cost of DNA bending," Trends in Biochemical Sciences, vol. 34, no. 9, pp. 464-470, 2009.

[151] J. Kasparkova, M. Vojtiskova, G. Natile, and V. Brabec, "Unique properties of DNA interstrand cross-links of antitumor oxaliplatin and the effect of chirality of the carrier ligand," Chemistry - A European Journal, vol. 14, no. 4, pp. 1330-1341, 2008.

[152] J.-C. Huang, D. B. Zamble, J. T. Reardon, S. J. Lippard, and A. Sancar, "HMG-domain proteins specifically inhibit the repair of the major DNA adduct of the anticancer drug cisplatin by human excision nuclease," Proceedings of the National Academy of Sciences of the United States of America, vol. 91, no. 22, pp. 10394-10398, 1994.

[153] A. Sharma, A. Ramanjaneyulu, R. Ray, and M. R. Rajeswari, "Involvement of high mobility group B proteins in cisplatininduced cytotoxicity in squamous cell carcinoma of skin," DNA and Cell Biology, vol. 28, no. 7, pp. 311-318, 2009.

[154] C. S. Chow, J. P. Whitehead, and S. J. Lippard, "HMG domain proteins induce sharp bends in cisplatin-modified DNA," Biochemistry, vol. 33, no. 50, pp. 15124-15130, 1994.

[155] E. E. Trimmer, D. B. Zamble, S. J. Lippard, and J. M. Essigmann, "Human testis-determining factor SRY binds to the major DNA adduct of cisplatin and a putative target sequence with comparable affinities," Biochemistry, vol. 37, no. 1, pp. 352-362, 1998.

[156] K. Chválová, M.-A. Sari, S. Bombard, and J. Kozelka, "LEF1 recognition of platinated GG sequences within doublestranded DNA. Influence of flanking bases," Journal of Inorganic Biochemistry, vol. 102, no. 2, pp. 242-250, 2008.
[157] M. Fuxreiter, N. Luo, P. Jedlovszky, I. Simon, and R. Osman, "Role of base flipping in specific recognition of damaged DNA by repair enzymes," Journal of Molecular Biology, vol. 323, no. 5, pp. 823-834, 2002.

[158] W. Yang, "Poor base stacking at DNA lesions may initiate recognition by many repair proteins," DNA Repair, vol. 5, no. 6, pp. 654-666, 2006.

[159] W. Yang, "Structure and mechanism for DNA lesion recognition," Cell Research, vol. 18, no. 1, pp. 184-197, 2008.

[160] C.-G. Yang, K. Garcia, and C. He, "Damage detection and base flipping in direct DNA alkylation repair," ChemBioChem, vol. 10, no. 3, pp. 417-423, 2009.

[161] D. R. Duckett, J. T. Drummond, A. I. H. Murchie, et al., "Humnan MutS $\alpha$ recognizes damaged DNA base pairs containing O6-methylguanine, O4-methylthymine, or the cisplatin-d(GpG) adduct," Proceedings of the National Academy of Sciences of the United States of America, vol. 93, no. 13, pp. 6443-6447, 1996.

[162] S. Aebi, B. Kurdi-Haidar, R. Gordon et al., "Loss of DNA mismatch repair in acquired resistance to cisplatin," Cancer Research, vol. 56, no. 13, pp. 3087-3090, 1996.

[163] J. A. Mello, S. Acharya, R. Fishel, and J. M. Essigmann, "The mismatch-repair protein hMSH2 binds selectively to DNA adducts of the anticancer drug cisplatin," Chemistry and Biology, vol. 3, no. 7, pp. 579-589, 1996.

[164] L. Fourrier, P. Brooks, and J.-M. Malinge, "Binding discrimination of MutS to a set of lesions and compound lesions (base damage and mismatch) reveals its potential role as a cisplatin-damaged DNA sensing protein," The Journal of Biological Chemistry, vol. 278, no. 23, pp. 21267-21275, 2003.

[165] M. Castellano-Castillo, H. Kostrhunova, V. Marini et al., "Binding of mismatch repair protein MutS to mispaired DNA adducts of intercalating ruthenium(II) arene complexes," The Journal of Biological Inorganic Chemistry, vol. 13, no. 6, pp. 993-999, 2008.

[166] O. Nováková, J. Kasparkova, V. Bursova et al., "Conformation of DNA modified by monofunctional $\mathrm{Ru}(\mathrm{II})$ arene complexes: recognition by DNA binding proteins and repair. Relationship to cytotoxicity," Chemistry and Biology, vol. 12, no. 1, pp. 121-129, 2005.

[167] L. Jia, K. Kropachev, S. Ding, B. Van Houten, N. E. Geacintov, and S. Broyde, "Exploring damage recognition models in prokaryotic nucleotide excision repair with a benzo[a]pyrene-derived lesion in UvrB," Biochemistry, vol. 48, no. 38, pp. 8948-8957, 2009.

[168] V. Mocquet, K. Kropachev, M. Kolbanovskiy et al., "The human DNA repair factor XPC-HR23B distinguishes stereoisomeric benzo[a]pyrenyl-DNA lesions," The EMBO Journal, vol. 26, no. 12, pp. 2923-2932, 2007.

[169] A. Hartwig, "The role of DNA repair in benzene-induced carcinogenesis," Chemico-Biological Interactions, vol. 184, no. 1-2, pp. 269-272, 2010.

[170] A. Janićijević, K. Sugasawa, Y. Shimizu et al., "DNA bending by the human damage recognition complex XPC-HR23B," DNA Repair, vol. 2, no. 3, pp. 325-336, 2003.

[171] F. C. Clement, U. Camenisch, J. Fei, N. Kaczmarek, N. Mathieu, and H. Naegeli, "Dynamic two-stage mechanism of versatile DNA damage recognition by xeroderma pigmentosum group C protein," Mutation Research, vol. 685, no. 1-2, pp. 21-28, 2010.

[172] K. L. Brown, M. Roginskaya, Y. Zou, A. Altamirano, A. K. Basu, and M. P. Stone, "Binding of the human nucleotide excision repair proteins XPA and XPC/HR23B 
to the $5 R$-thymine glycol lesion and structure of the cis$(5 R, 6 S)$ thymine glycol epimer in the $5^{\prime}-\mathrm{GTgG}-3^{\prime}$ sequence: destabilization of two base pairs at the lesion site," Nucleic Acids Research, vol. 38, no. 2, pp. 428-440, 2009.

[173] J. Yang, X. Liu, P. Niu, Y. Zou, and Y. Duan, "Correlations and co-localizations of Hsp70 with XPA, XPG in human bronchial epithelia cells exposed to benzo[a]pyrene," Toxicology, vol. 265, no. 1-2, pp. 10-14, 2009.

[174] K. Shinmura, M. Iwaizumi, H. Igarashi et al., "Induction of centrosome amplification and chromosome instability in p53-deficient lung cancer cells exposed to benzo $[\alpha]$ pyrene diol epoxide (B $[\alpha]$ PDE)," Journal of Pathology, vol. 216, no. 3, pp. 365-374, 2008.

[175] X. Lu, J. Shao, H. Li, and Y. Yu, "Early whole-genome transcriptional response induced by benzo $[\alpha]$ pyrene diol epoxide in a normal human cell line," Genomics, vol. 93, no. 4, pp. 332-342, 2009.

[176] X. Lu, J. Shao, H. Li, and Y. Yu, "Temporal gene expression changes induced by a low concentration of benzo $[\alpha]$ pyrene diol epoxide in a normal human cell line," Mutation Research, vol. 684, no. 1-2, pp. 74-80, 2010.

[177] Y. Cai, D. J. Patel, N. E. Geacintov, and S. Broyde, "Differential nucleotide excision repair susceptibility of bulky DNA adducts in different sequence contexts: hierarchies of recognition signals," Journal of Molecular Biology, vol. 385, no. 1, pp. 30-44, 2009.

[178] D. Chen, A. Kolbanovskiy, A. Shastry, et al., "Nucleotide excision repair of DNA adducts derived from the binding of the equine estrogen metabolite 4-OHEN to dC and dA adducts in vitro," in Proceedings of the 97th Annual Meeting of the American Association for Cancer Research, vol. 47, AACR, Washington, DC, USA, April 2006, abstract no. \#5255.

[179] E. G. Notch, D. M. Miniutti, and G. D. Mayer, " $17 \alpha-$ ethinylestradiol decreases expression of multiple hepatic nucleotide excision repair genes in zebrafish (Danio rerio)," Aquatic Toxicology, vol. 84, no. 3, pp. 301-309, 2007.

[180] E. G. Notch and G. D. Mayer, "17 $\alpha$-ethinylestradiol hinders nucleotide excision repair in zebrafish liver cells," Aquatic Toxicology, vol. 95, pp. 273-278, 2009.

[181] S. Depauw, T. Gaslonde, S. Léonce, et al., "Influence of the stereoisomeric position of the reactive acetate groups of the benzo[b]acronycine derivative S23906-1 on its DNA alkylation, helix-opening, cytotoxic, and antitumor activities," Molecular Pharmacology, vol. 76, no. 6, pp. 1172-1185, 2009.

[182] C. J. Rocca, V. Poindessous, D. G. Soares, et al., "The NER proteins XPC and CSB, but not ERCC1, regulate the sensitivity to the novel DNA binder S23906: implications for recognition and repair of antitumor alkylators," Biochemical Pharmacology, vol. 80, no. 3, pp. 335-343, 2010.

[183] A. B. Herrero, C. Martín-Castellanos, E. Marco, F. Gago, and S. Moreno, "Cross-talk between nucleotide excision and homologous recombination DNA repair pathways in the mechanism of action of antitumor trabectedin," Cancer Research, vol. 66, no. 16, pp. 8155-8162, 2006. 

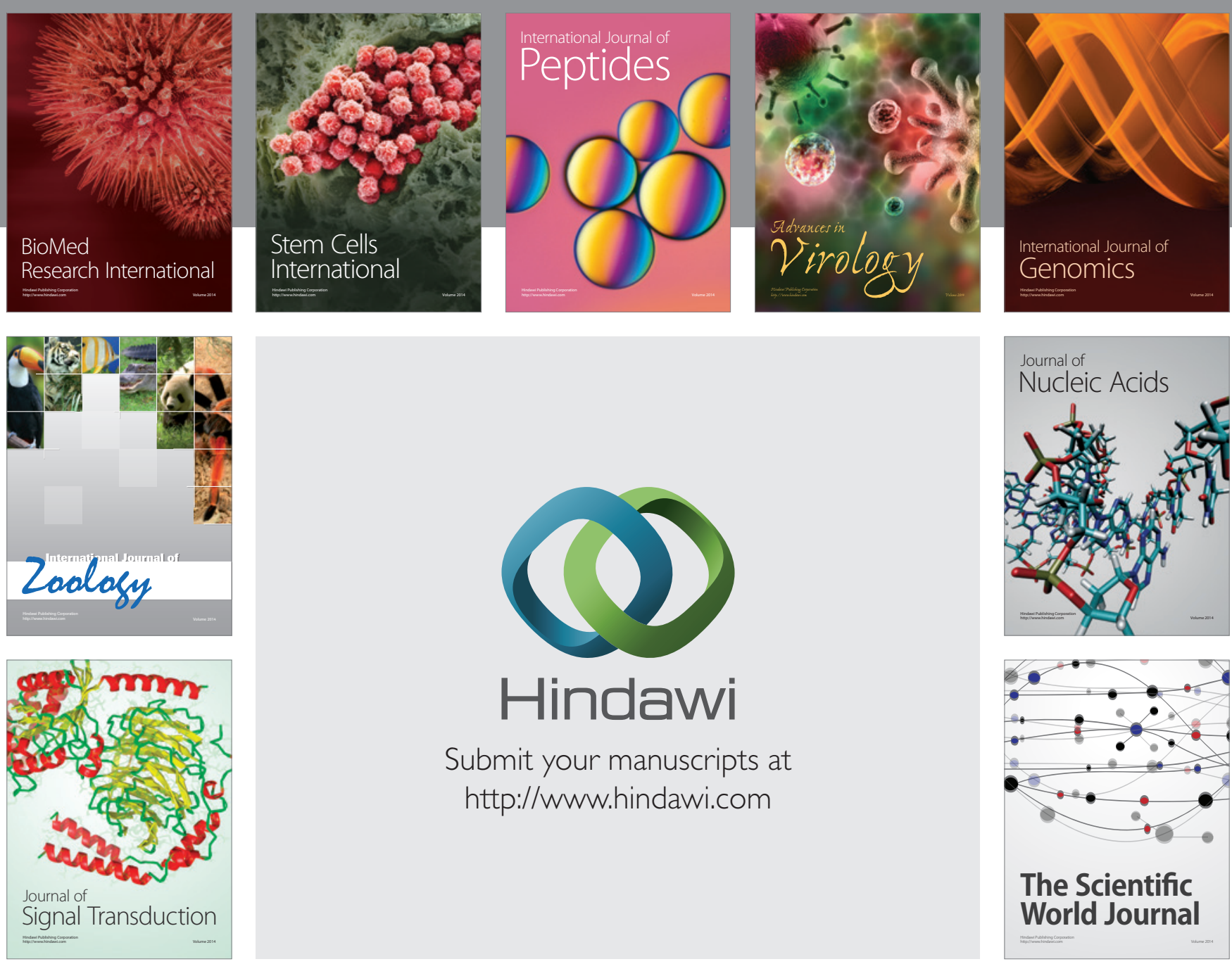

Submit your manuscripts at

http://www.hindawi.com
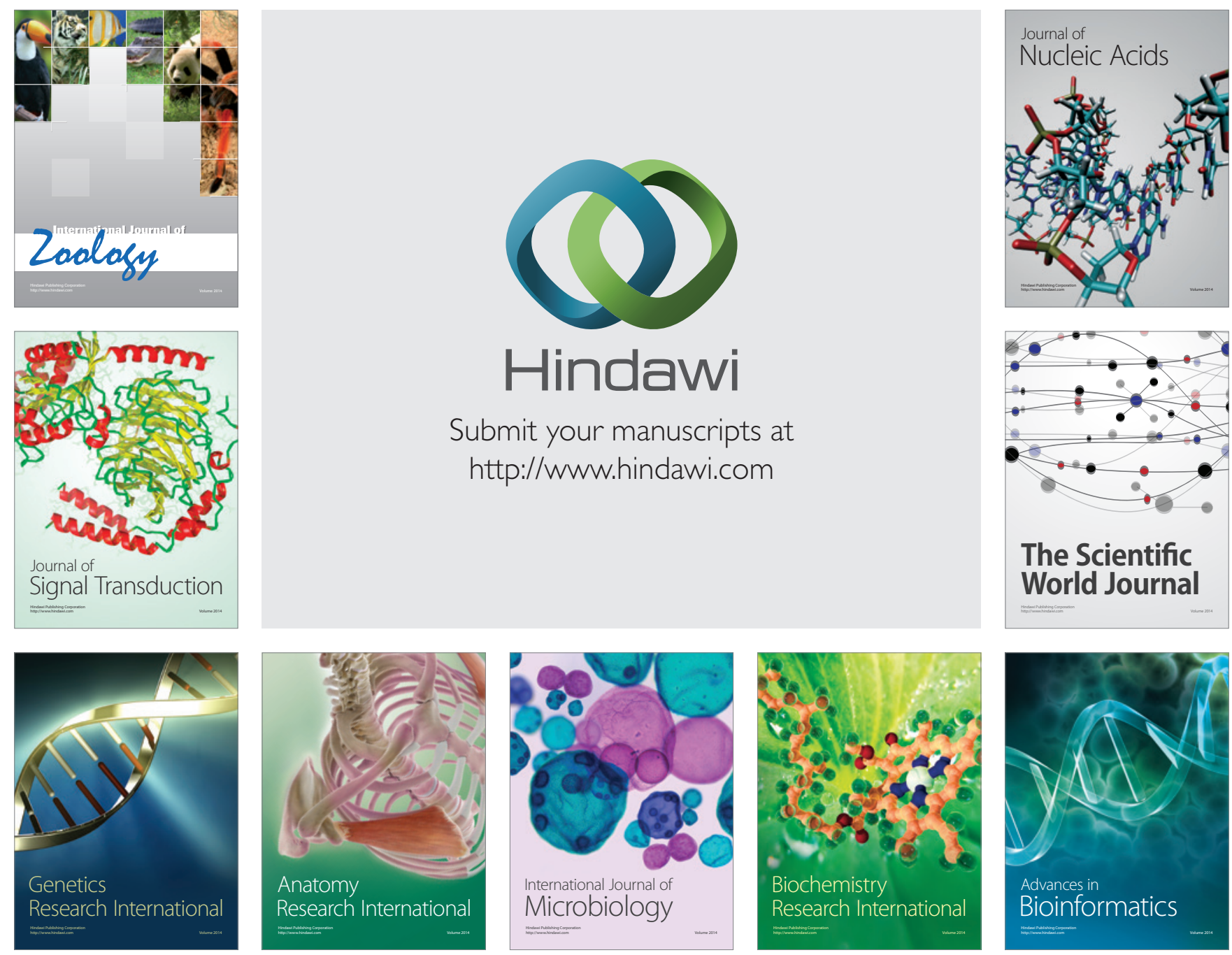

The Scientific World Journal
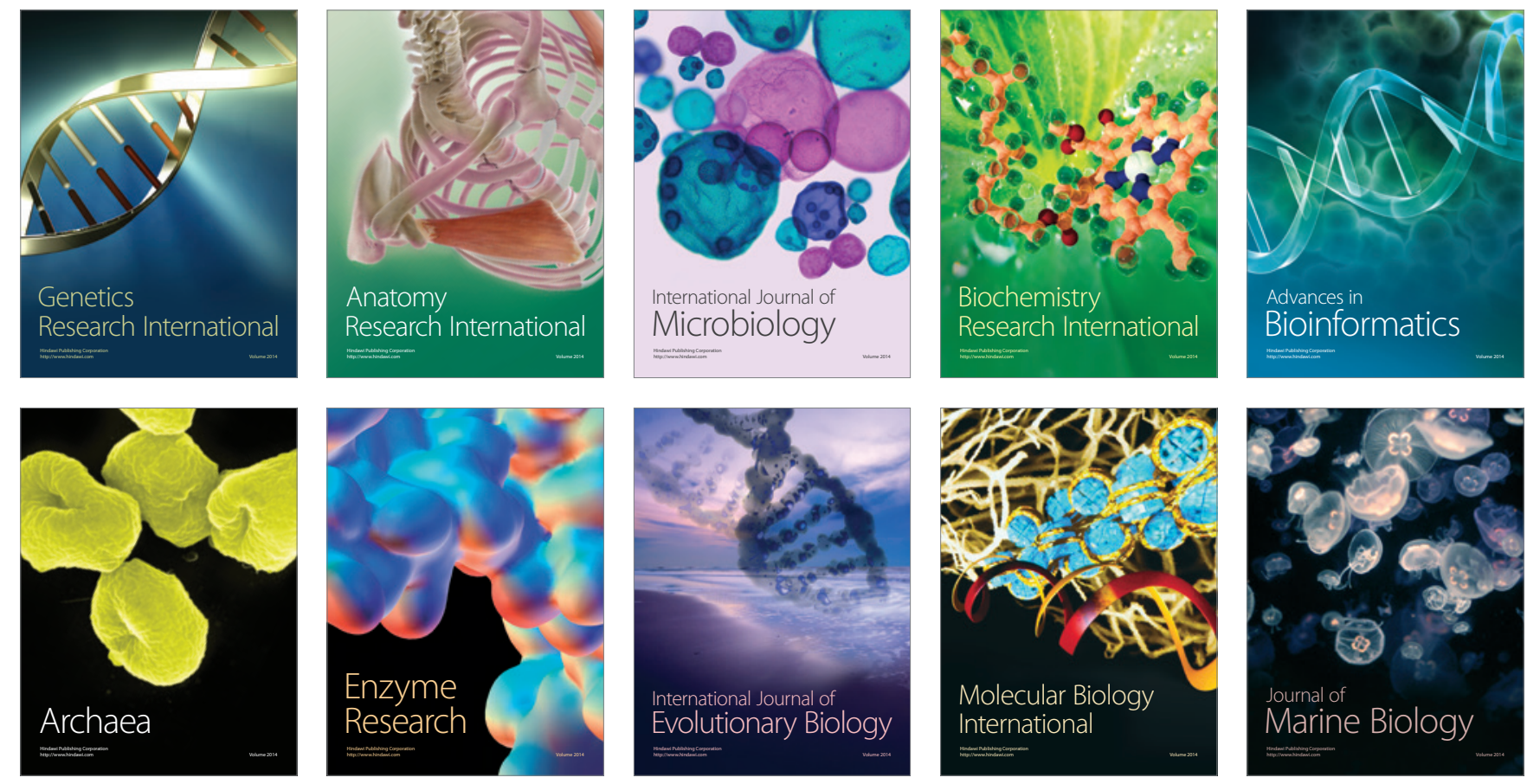